\title{
Lipophilic components of diesel exhaust particles induce pro-inflammatory responses in human endothelial cells through AhR dependent pathway(s)
}

Bendik C. Brinchmann ${ }^{1,2}$, Tonje Skuland ${ }^{1}$, Mia H. Rambøl ${ }^{3}$, Krisztina Szoke 3 , Jan E. Brinchmann ${ }^{3}$, Arno C. Gutleb ${ }^{4}$, Elisa Moschini ${ }^{4}$, Alena Kubátová ${ }^{5}$, Klara Kukowski ${ }^{5}$, Eric Le Ferrec ${ }^{6,7}$, Dominique Lagadic-Gossmann ${ }^{6,7}$,

Per E. Schwarze ${ }^{1}$, Marit Låg ${ }^{1}$, Magne Refsnes ${ }^{1}$, Johan Øvrevik ${ }^{1}$ and Jørn A. Holme ${ }^{1 *}$ (i)

\begin{abstract}
Background: Exposure to traffic-derived particulate matter (PM), such as diesel exhaust particles (DEP), is a leading environmental cause of cardiovascular disease (CVD), and may contribute to endothelial dysfunction and development of atherosclerosis. It is still debated how DEP and other inhaled PM can contribute to CVD. However, organic chemicals (OC) adhered to the particle surface, are considered central to many of the biological effects. In the present study, we have explored the ability of OC from DEP to reach the endothelium and trigger proinflammatory reactions, a central step on the path to atherosclerosis.

Results: Exposure-relevant concentrations of DEP $\left(0.12 \mu \mathrm{g} / \mathrm{cm}^{2}\right)$ applied on the epithelial side of an alveolar 3D triculture, rapidly induced pro-inflammatory and aryl hydrocarbon receptor (AhR)-regulated genes in the basolateral endothelial cells. These effects seem to be due to soluble lipophilic constituents rather than particle translocation. Extractable organic material of DEP (DEP-EOM) was next fractionated with increasing polarity, chemically characterized, and examined for direct effects on pro-inflammatory and AhR-regulated genes in human microvascular endothelial (HMEC-1) cells and primary human endothelial cells (PHEC) from four healthy donors. Exposure-relevant concentrations of lipophilic DEP-EOM $\left(0.15 \mu \mathrm{g} / \mathrm{cm}^{2}\right)$ induced low to moderate increases in IL-1a, IL-1 $\beta$, COX2 and MMP-1 gene expression, and the MMP- 1 secretion was increased. By contrast, the more polar EOM had negligible effects, even at higher concentrations. Use of pharmacological inhibitors indicated that AhR and protease-activated receptor-2 (PAR-2) were central in regulation of EOM-induced gene expression. Some effects also seemed to be attributed to redox-responses, at least at the highest exposure concentrations tested. Although the most lipophilic EOM, that contained the majority of PAHs and aliphatics, had the clearest low-concentration effects, there was no straight-forward link between chemical composition and biological effects.

Conclusion: Lipophilic and semi-lipophilic chemicals seemed to detach from DEP, translocate through alveolar epithelial cells and trigger pro-inflammatory reactions in endothelial cells at exposure-relevant concentrations. These effects appeared to be triggered by AhR agonists, and involve PAR-2 signaling.
\end{abstract}

Keywords: Air pollution, Diesel exhaust particles, Inflammation, Cardiovascular disease, Atherosclerosis, Endothelial cells, 3D tri-culture, Organic compounds, Aryl hydrocarbon receptor

\footnotetext{
* Correspondence: jorn.holme@fhi.no

${ }^{1}$ Department of Air Pollution and Noise, Domain of Infection Control,

Environment and Health, Norwegian Institute of Public Health, PO Box 4404,

Nydalen, N-0403 Oslo, Norway

Full list of author information is available at the end of the article
}

(c) The Author(s). 2018 Open Access This article is distributed under the terms of the Creative Commons Attribution 4.0 International License (http://creativecommons.org/licenses/by/4.0/), which permits unrestricted use, distribution, and

reproduction in any medium, provided you give appropriate credit to the original author(s) and the source, provide a link to the Creative Commons license, and indicate if changes were made. The Creative Commons Public Domain Dedication waiver (http://creativecommons.org/publicdomain/zero/1.0/) applies to the data made available in this article, unless otherwise stated. 


\section{Background}

More than $90 \%$ of the world's population live in areas with unhealthy air according to WHO [1]. Particulate matter (PM), especially fine $\mathrm{PM}\left(\mathrm{PM}_{2.5}\right)$, is a leading environmental cause of cardiovascular disease (CVD) [2-5], and has been linked to development and exacerbation of endothelial dysfunction and atherosclerosis in a number of experimental and epidemiological studies [6-8]. Atherosclerosis is initiated by endothelial dysfunction and can lead to myocardial infarction, cerebrovascular and peripheral vascular disease [9], making it the major cause of deaths due to CVD [10]. It is an inflammatory disorder of the arteries, a process that involves oxidative stress, increased endothelial permeability, leukocyte adhesion and other inflammatory reactions [11].

Diesel engines are major contributors to $\mathrm{PM}_{2.5}$ in urban environments $[12,13]$. Thus, diesel exhaust particles (DEP) have frequently been used as a model to explore the mechanisms of PM-induced CVD [14, 15]. Much of the biological effects of DEP, including pro-inflammatory responses, have been attributed to soluble organic chemicals $(\mathrm{OC})$ adherent to the carbon core of the particles [1619]. How DEP and other inhaled PM can cause adverse effects in the endothelium is still debated despite extensive research. One common theory is that PM may cause pulmonary macrophages and epithelial cells to release proinflammatory mediators into the circulation, leading to systemic effects [20]. However, a recent review concluded that neither pulmonary nor systemic inflammation is a prerequisite for PM-induced atherosclerosis or endothelial dysfunction [14]. An alternative explanation is that $\mathrm{PM}_{2.5}$ and its constituents could affect endothelial cells more directly. Recently, inhaled gold nanoparticles $(2-200 \mathrm{~nm})$ were shown to translocate from the lung into the circulation and preferentially accumulated at sites of inflammatory vascular lesions in mice and humans [21]. This suggests that nanosized combustion particles may also be transported to sites of endothelial injury in a similar way. Thus, DEP translocated into the circulation, may deliver its "organic cargo" directly to endothelial cells. However, studies using model particles rich in polycyclic aromatic hydrocarbons (PAH) suggest that PAHs are released from the particles, passes through the alveolar wall into the circulation, and are distributed systemically [22-24]. This suggests that translocation of DEP and other combustion particles across the alveolar wall may not be necessary for soluble $\mathrm{OC}$ to be transferred into the circulation and reach the endothelium, also distant from the lung.

Although pulmonary and systemic inflammation may not be the prime drivers of adverse PM-induced effects on the endothelium [14], inflammatory responses have nevertheless a key role in endothelial dysfunction and atherosclerosis. Pro-inflammatory mediators such as cytokines, chemokines and matrix metalloproteinases (MMPs) are crucial in the different developmental stages of the disease, and endothelial cells appear to orchestrate these events $[11,25]$. In line with this, inflammation and oxidative stress in the arterial wall seems consistently associated with PM-induced vasomotor dysfunction and plaque progression [14]. Thus, local rather than systemic inflammation may be a prerequisite for development of endothelial dysfunction by PM-exposure.

DEP appear to cause cellular effects through multiple mechanisms, and the pro-inflammatory effects most likely arise from the combined activation of several pathways [26, 27]. It is known that PAHs and other OC from DEP can bind the aryl hydrocarbon receptor (AhR), which in turn may lead to an increased expression of genes linked to inflammation and xenobiotic metabolism [28]. AhR may regulate inflammation through nongenomic signaling, cross-talk with transcription factors such as the nuclear factor- $\mathrm{kB}(\mathrm{NF}-\mathrm{kB})$, and some cytokines also contain AhR-response elements in their promotor region [29, 30]. Furthermore, metabolism of OC from DEP by various cytochrome P450 (CYP) enzymes may form reactive oxygen species (ROS) and reactive electrophilic metabolites [31] with potential to trigger inflammation. In addition, recent studies suggest that the protease activated receptor-2 (PAR-2), a G-protein coupled receptor, regulates matrix metalloproteinase-1 (MMP-1) and interleukin-6 (IL-6) in human bronchial epithelial cells exposed to DEP and DEP-EOM [17, 32]. PARs are also constitutively expressed in the vascular endothelium where they regulate tone, permeability and coagulation as well as inflammation [33, 34]. Thus, AhR and PAR-2 as well as redox-regulated responses could likely be involved in the effects of DEP and OC from DEP in endothelial cells.

In the present study we have explored potential mechanisms involved in PM-induced endothelial inflammation by various in vitro models, using DEP as a surrogate for traffic-derived PM. We asked: i) does DEP affect endothelial cells via $\mathrm{OC}$, ii) which classes of chemicals in DEP-OC are inducing inflammatory reactions, and iii) which cellular mechanisms are involved. The use of exposure-relevant concentrations/doses in vitro are important to ensure that the mechanisms explored could be relevant for adverse effects in real-life [35]. Based on in vivo calculations for high-risk individuals exposed to PM levels of $79 \mu \mathrm{g} / \mathrm{m}^{3}, \mathrm{Li}$ and coworkers estimated $\mathrm{PM}_{2}$. ${ }_{5}$ deposition rates over $24 \mathrm{~h}$ to be $204 \mu \mathrm{g} / \mathrm{cm}^{2}$ in the nasopharyngeal, $2.3 \mu \mathrm{g} / \mathrm{cm}^{2}$ in the tracheobronchial and $0.05 \mu \mathrm{g} / \mathrm{cm}^{2}$ in the alveolar regions [36]. Acknowledging that our in vitro systems were bolus-exposed, an additional central focus was to explore effects at these concentrations. We found that DEP applied on the apical surface of alveolar cells in a 3D tri-culture model of the alveolar-capillary barrier, induced expression of pro- 
inflammatory genes and markers of AhR-signaling in the basolateral endothelial cells at concentrations down to exposure-relevant levels. These responses appeared not to depend on particle translocation. By exposing endothelial cell monocultures (HMEC-1 and primary human endothelial cells; PHEC) to fractionated extractable organic material of DEP (DEP-EOM), we confirmed that DEP-EOM induced inflammation-associated genes through mechanisms partly depending on AhR, PAR-2 and redox responses. At the lowest, most exposurerelevant concentrations, the most lipophilic DEP-EOM seemed to have the strongest effects on the expression of pro-inflammatory genes in HMEC-1 and PHEC. This DEP-EOM fraction also had the highest content of semivolatile OC, especially PAHs and aliphatic hydrocarbons.

\section{Results}

\section{DEP-induced gene expression in 3D tri-culture model}

We hypothesized that OC from DEP could translocate through alveolar epithelial cells and reach endothelial cells. To test this we utilized an established 3D triculture composed of alveolar type-II A549 cells and macrophage-differentiated THP-1 cells on the apical (epithelial) side of a microporous membrane and endothelial cells (EA.hy926) on the basolateral side [37, 38]. We define the model as a 3D tri-culture model of the alveolar-capillary barrier based on the 3D interaction between the various cells at both sides of the insert as described by Klein et al. [38, 39]. This 3D tri-culture model was exposed to different concentrations of DEP at the epithelial side for 2 and $20 \mathrm{~h}$. The DEP that previously have been characterized by Totlandsdal et al. [40], rapidly induced pro-inflammatory and AhR-regulated genes in cells on both the epithelial side and the endothelial side of the 3D tri-culture (Fig. 1). More specifically, IL-1 $\alpha$ (2-5 fold), PAI-2 (3-15 fold) and CYP1B1 (8-40 fold) mRNA expressions were up-regulated in cells on the epithelial side. The up-regulations observed in EA.hy926 cells were in general similar to those on the epithelial side. However, DEP induced COX-2 expression in EA.hy926 (3-10 fold), in the absence of any apparent response on the epithelial side. This increase was statistically significant already after $2 \mathrm{~h}$ exposure to the lowest concentration tested $\left(0.5 \mu \mathrm{g} / \mathrm{mL}\right.$ or $\left.0.12 \mu \mathrm{g} / \mathrm{cm}^{2}\right)$. At the highest concentration, DEP also induced a 2 -fold increase in MMP-1 expression in the endothelial cells, whereas cells on the epithelial side did not up-regulate MMP-1 (Fig. 1). In contrast, $\mathrm{SiO}_{2}$ nanoparticles (SiNP) used as control particles without soluble OC only activated gene expression at the epithelial side and not in the endothelial cells of the tri-culture (Additional file 1: Figure S1A), despite being able to trigger a substantial COX-2 increase when exposed directly to EA.hy926 cells in monoculture (Additional file 1: Figure S1B).This suggests that nanoparticles did not reach the endothelial cells through the layer of epithelial cells in the triculture, at least not in sufficient quantities to trigger a response. The most likely interpretation of these findings is that particles were not translocated into the endothelial layer of the 3D model, and that the endothelial responses to DEP-exposure were rather due to soluble OCs passing through the epithelial layer.

\section{Chemical characterization of various DEP-EOM}

The above results support a major role of soluble $\mathrm{OC}$ in the effects of DEP. We therefore extracted organic material from DEP by sequential washing under pressure at $100{ }^{\circ} \mathrm{C}$, with solvents of increasing polarity: $n$-hexane, dichloromethane (DCM), and methanol, followed by a final washing with water at $25{ }^{\circ} \mathrm{C}$. The chemical compositions of these four fractions, from here on referred to as $n$-Hex-EOM, DCM-EOM, Methanol-EOM and Water-EOM, were analyzed for total content of carbon, amount of PAHs (and their derivatives) and aliphatic hydrocarbons (Fig. 2). In line with previous analyses, the relative amount of organic versus elemental carbon in this DEP was approximately 60 and $10 \%$, respectively [41]. As expected for DEP [41], we found that most of the $\mathrm{OC}$ was extracted with $n$-hexane and DCM, with remaining 19\% recovered in the methanol extract. OC was not detected in the water extract. The most lipophilic $n$-hexane extract contained almost $90 \%$ of the PAHs and aliphatic hydrocarbons, while the rest was obtained with DCM (see Additional file 1: Table S1, for an overview of detected species). The relative amount of different PAH species corresponded to previous analyses [41] with phenanthrene (and methylated phenanthrene or anthracene), fluoranthene, pyrene, chrysene, xanthone and 1nitropyrene being the most abundant species detected (data not shown). Notably, the amount of volatile/semi-volatile compounds extracted also decreased according to polarity of the solvents (Additional file 1: Figure S2).

\section{DEP-EOM-induced gene-expression in HMEC-1}

The observed effects on endothelial cells in the 3D triculture exposed to a DEP rich in OC, combined with the previously reported marginal effects on endothelial cells in a comparable 3D tetra-culture exposed to DEP (SRM2975) with little OC, strongly suggests an important role of OC from DEP. Although the extracts not necessarily reflects the specific compounds reaching the endothelial cells of the 3D tri-culture, they contain a mixture of OC similar to what has been reported in other studies on DEP [41, 42]. We next investigated if endothelial cells exposed directly to DEP-EOM responded in a similar manner as the endothelial cells exposed indirectly to DEP through the epithelial cells in the 3D tri-culture. As the EA.hy926 cell line used in the 3D tri-culture is a endothelial/epithelial hybrid [43], we chose another well described endothelial cell line for the 

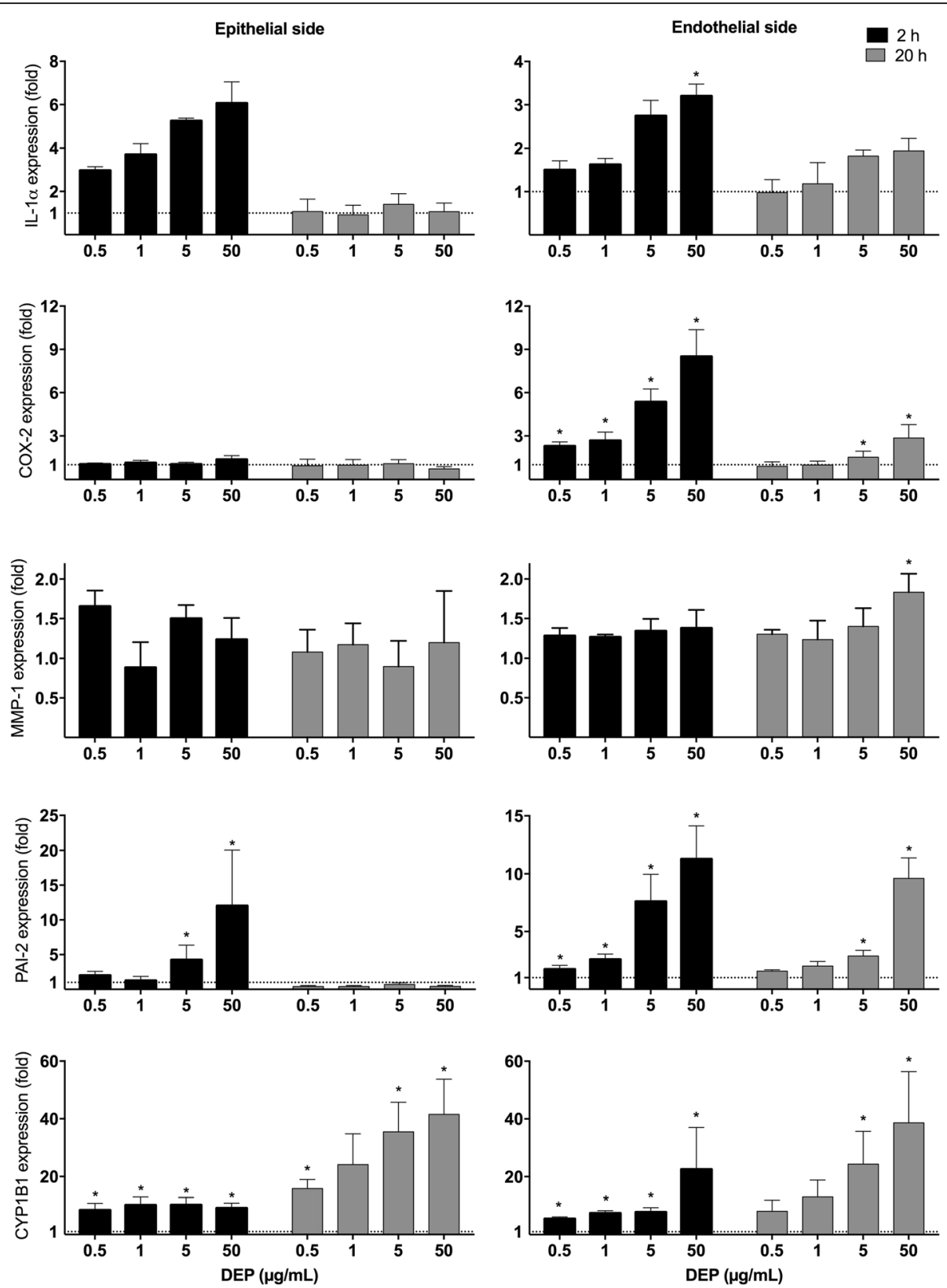

Fig. 1 Effect of DEP exposure on gene expression in a 3D tri-culture model. Increasing concentrations of DEP were applied to the epithelial side of the 3D tri-culture. After 2 and $20 \mathrm{~h}$ of exposure, alveolar and endothelial cells were harvested and the expressions of IL-1a, COX-2, MMP-1, PAI-2 (SERPINB2) and CYP1B1 mRNAs were measured by q-PCR. The mRNA levels are presented relative to gene expression in cells exposed to DMSO, represented by the dotted line at 1 . The results are expressed as mean \pm SEM $(n=3)$. *Statistically significant difference from unexposed controls

next experiments: the HMEC-1 cells which are of microvascular origin [44].

HMEC-1 were exposed to DEP-EOM concentrations of 5 and $50 \mu \mathrm{g} / \mathrm{mL}$ corresponding to 0.75 and $7.5 \mu \mathrm{g} / \mathrm{cm}^{2}$ of originally unwashed DEP. These concentrations did not appear to be cytotoxic, as initially screened by the WST-1 proliferation assay and judged visually by microscopy (Additional file 1: Figure S3). IL-1 $\alpha / \beta$, IL-6, CXCL8, MMP-1 and COX-2 mRNA concentrations were measured to explore pro-inflammatory effects. ROSrelated effects were addressed by assessing HO-1 expression and AhR activity by measuring the AhR response genes CYP1A1, -1B1 and PAI-2. The lipophilic DEP-EOM fractions, particularly at the highest concentration, increased the expression of the pro-inflammatory genes measured (Fig. 3). The effects on CXCL8 expression and lack of effect on IL-6 expression was further confirmed by ELISA, showing that CXCL8 protein (but not IL-6) was 


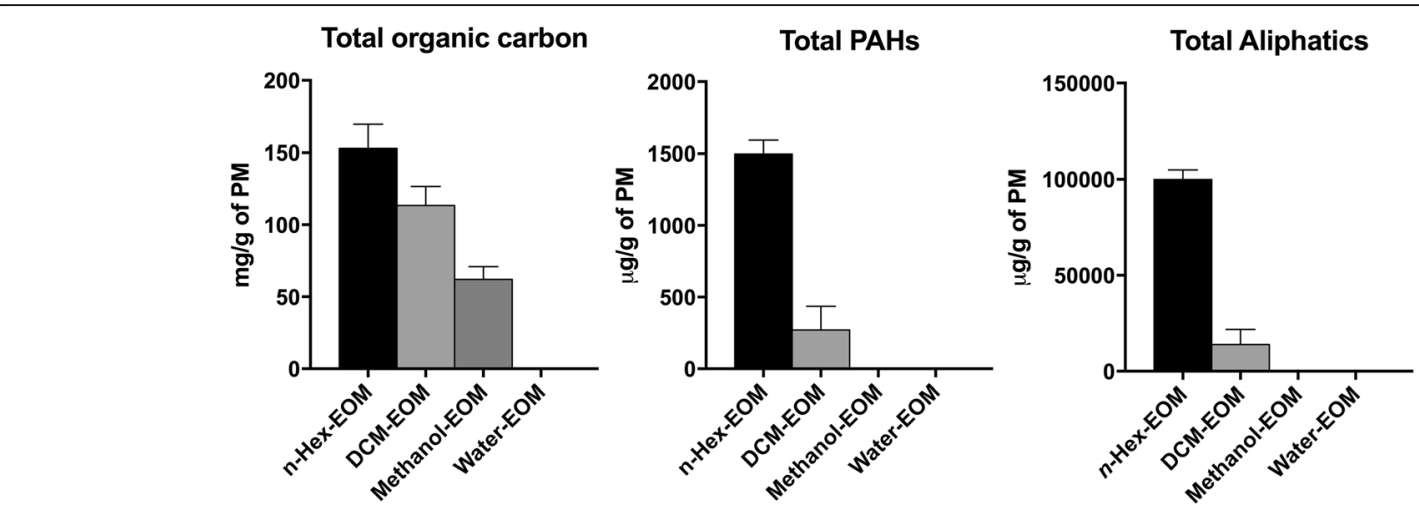

Fig. 2 Characterization of DEP-EOM. The soluble organic carbon/chemicals were extracted directly from the native particulates by sequential washing with $\mathrm{n}$-hexane, DCM and methanol at $100^{\circ} \mathrm{C}$ (under pressure), followed by a final washing with water at $25^{\circ} \mathrm{C}$. Total content of organic carbon was analyzed by thermal optical analysis, while content of PAHs and aliphatics were measured by GC-FID/MIS, as described under materials and methods. The extraction was done in three parallels and the results are expressed as mean $\pm \operatorname{SEM}(n=3)$

secreted by HMEC-1 cells upon $24 \mathrm{~h}$ exposure to the $n$ Hex- and DCM-EOM $(50 \mu \mathrm{g} / \mathrm{mL})$, but not by the methanol and water extracts (Additional file 1: Figure S4). Most interestingly, expression of IL-1 $\alpha$, COX-2, and MMP-1 was increased (2-3 fold) at the low concentration of the $n$ hexane extract, corresponding to $5 \mu \mathrm{g} / \mathrm{mL}\left(0.75 \mu \mathrm{g} / \mathrm{cm}^{2}\right)$ of original DEP (Fig. 3). In addition, the low concentration of the DCM extract also induced an increase in MMP-1 (2-fold) after $24 \mathrm{~h}$ (Fig. 3). The expression of the AhRresponse genes CYP1A1 and CYP1B1 was induced by both concentrations of all the fractions, but $n$-hexane- and DCM-EOM had more marked effects at the lowest

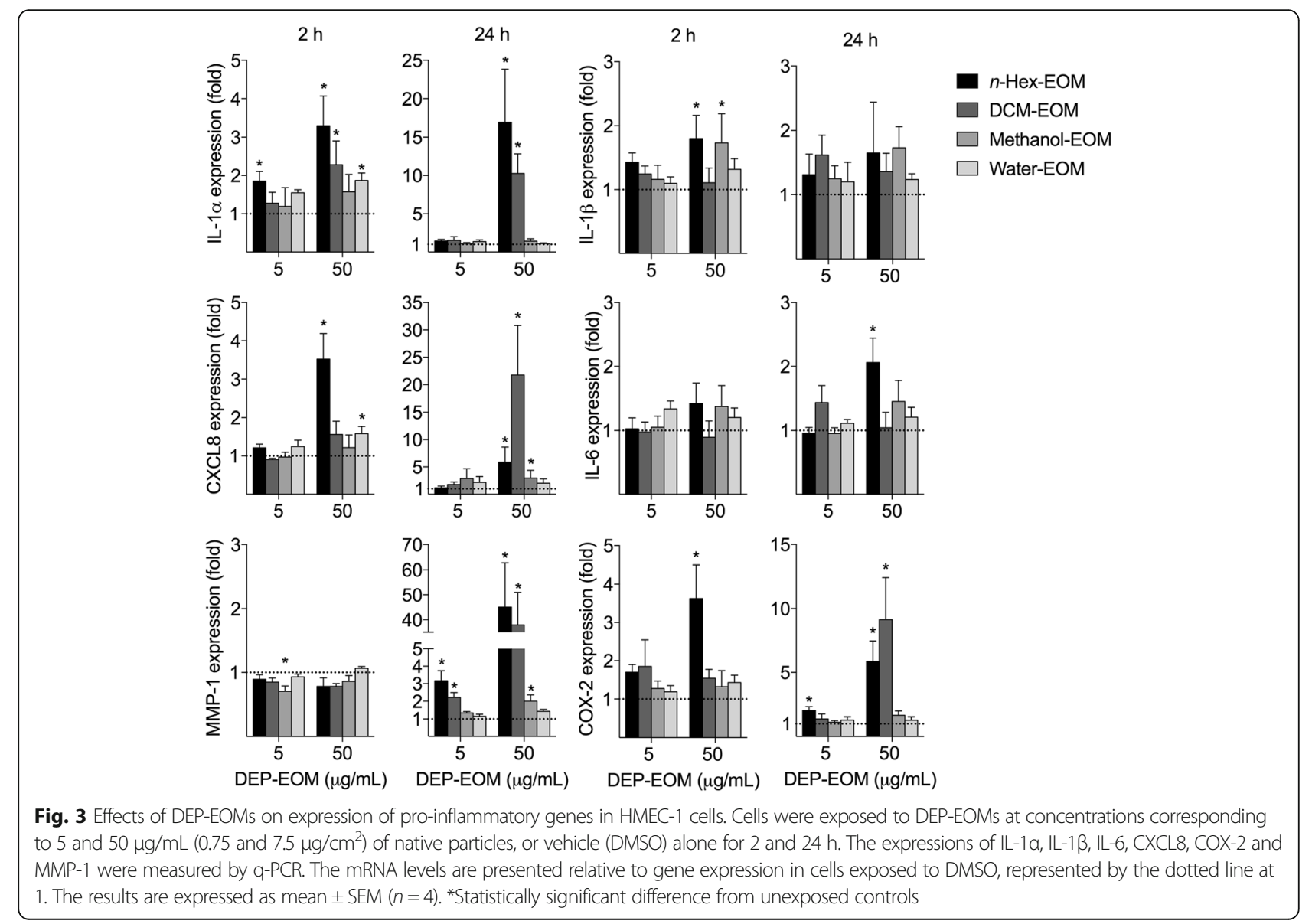


concentration (Fig. 4). Previous studies with this specific DEP have shown that CYP1A1-responses in bronchial epithelial BEAS-2B cells peaked at $4 \mu \mathrm{g} / \mathrm{cm}^{2}$, and were reduced at higher concentrations [40]. In line with this, the CYP1A1 and -1B1 responses induced by the two most potent DEP-EOM fractions ( $n$-hexane and DCM) also appeared to be reduced at the highest concentration (Fig. 4). The AhR response-gene PAI-2 [45] was induced by all fractions, except the water extract. Similar to the CYPresponses, PAI- 2 was more strongly increased by the $n$ Hex- and DCM-EOM, at least at low concentrations. Furthermore, HO-1 was only upregulated at $50 \mu \mathrm{g} / \mathrm{mL}$ and not at $5 \mu \mathrm{g} / \mathrm{mL}$, indicating that responses observed at the lowest concentration were triggered in the absence of measured oxidative stress.

The above results suggest that pro-inflammatory gene expression was predominately affected by the two most lipophilic DEP-EOM fractions: $n$-Hex- and DCM-EOM. At the lowest concentration, effects were the most pronounced for the $n$-hexane extract.

\section{DEP-EOM-induced gene-expression in PHEC}

The responses of cell lines used in our systems are not representative for real exposure. We thus further explored the relevance of our findings by using primary human endothelial cells (PHEC) obtained from adipose tissue of four healthy donors [46]. These PHEC were of high purity, as indicated by $99 \%$ CD31 positive cells (Additional file 1: Figure S5). The cells were exposed to low concentrations of the different DEP-EOM fractions, corresponding to 1 and $5 \mu \mathrm{g} / \mathrm{mL}\left(0.15\right.$ and $\left.0.75 \mu \mathrm{g} / \mathrm{cm}^{2}\right)$ of native particles, for $24 \mathrm{~h}$. No visual cytotoxicity was observed in cells exposed to either of the DEP-EOM fractions at the highest concentration, as exemplified with $n$-Hex-EOM (Additional file 1: Figure S3B).

As in HMEC-1, the lipophilic DEP-EOM fractions induced inflammation-associated genes, as well as CYP1A1 and CYP1B1 in PHEC, while the hydrophilic extracts had negligible effects (Fig. 5a). Most notably lipophilic DEPEOM caused statistically significant up-regulation (2-7 fold) of IL- $1 \alpha$, IL- $1 \beta$, COX-2 and MMP- 1 expression, even at the lowest concentration $(1 \mu \mathrm{g} / \mathrm{mL}$, corresponding to $0.15 \mu \mathrm{g} /$ $\mathrm{cm}^{2}$ of native particles), while CXCL8 and HO- 1 were unaffected after $24 \mathrm{~h}$ exposure. Furthermore, CYP1A1, CYP1B1 and PAI-2 were induced by all DEP-EOM fractions, except the water extract (Fig. 5a), and CYP1A1 and CYP1B1 mRNAs were more strongly induced in PHEC (15-90 fold), than in HMEC-1. Of interest, the MMP-1 mRNA up-regulation was confirmed with ELISA; MMP-1 protein levels were increased by $45-90 \%$ in PHEC exposed to $n$-Hex- or DCM-EOM (Fig. $5 \mathrm{~b}$ ).

\section{Mechanisms of DEP-EOM-induced gene expression in HMEC-1}

To elucidate the mechanisms involved in the regulation of the pro-inflammatory responses induced by $n$-Hexand DCM-EOM $(50 \mu \mathrm{g} / \mathrm{mL})$, we pretreated HMEC-1 cells with pharmacological inhibitors targeting AhR $(\mathrm{CH} 223191 ; 1.0 \mu \mathrm{M})$ or PAR-2 (ENMD-1068; $2.5 \mathrm{mM})$, and to target ROS we used the anti-oxidant $\mathrm{N}$ acetylcysteine (NAC; $2.0 \mathrm{mM}$ ). To minimize potential unspecific effects of the inhibitor/antioxidant treatment,


Fig. 4 Effects of DEP-EOMs on expression of HO-1 and AhR-regulated genes in HMEC-1 cells. Cells were exposed to DEP-EOMs at concentrations corresponding to 5 and $50 \mu \mathrm{g} / \mathrm{mL}\left(0.75\right.$ and $7.5 \mu \mathrm{g} / \mathrm{cm}^{2}$ ) of native particles, or vehicle (DMSO) alone for 2 and $24 \mathrm{~h}$. The expressions of CYP1A1, CYP1B1, PAI-2 and HO-1 were measured by q-PCR. The mRNA levels are presented relative to gene expression in cells exposed to DMSO, represented by the dotted line at 1 . The results are expressed as mean $\pm \operatorname{SEM}(n=4)$. *Statistically significant difference from unexposed controls 

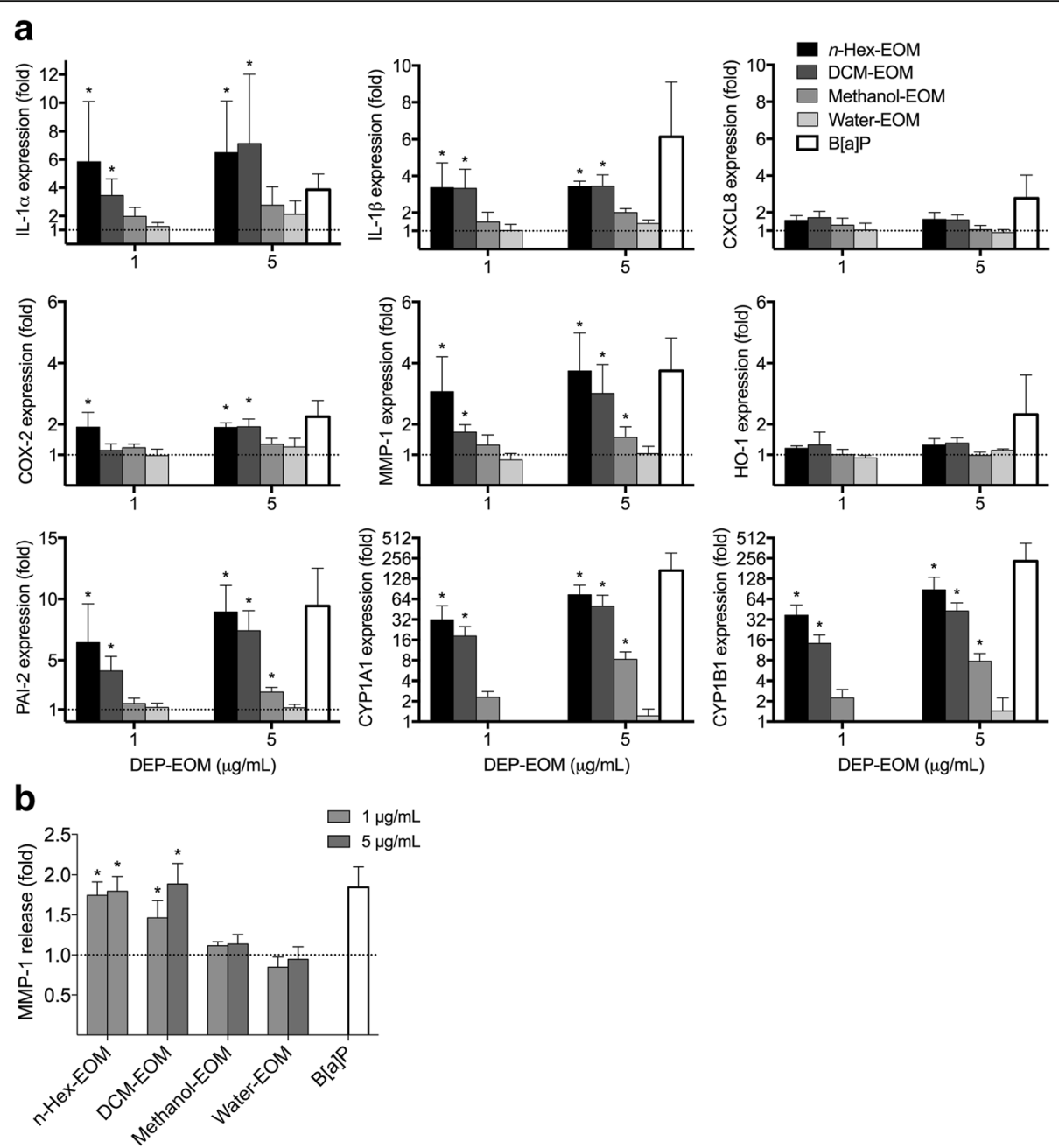

Fig. 5 Effects of lipophilic DEP-EOMs in PHEC. PHEC were exposed to DEP-EOM at concentrations corresponding to 1 or $5 \mu \mathrm{g} / \mathrm{mL}\left(0.15 \mathrm{and} 0.75 \mu \mathrm{g} / \mathrm{cm}^{2}\right)$ of native particles, vehicle (DMSO) or $1 \mu \mathrm{M}$ B[a]P (positive control) for $24 \mathrm{~h}$. The expressions of IL-1a, IL-13, CXCL8, COX2, MMP-1, HO-1, CYP1A1, CYP1B1 and PAl-2 was measured by q-PCR (a). MMP-1 up-regulation were confirmed with ELISA, showing 45-90\% higher levels of MMP-1 in growth medium from PHEC exposed to $n$-hexane or DCM (b). The mRNA levels are presented relative to gene expression in cells exposed to DMSO, represented by the dotted line at 1. Data are based on results from experiments with PHEC from 4 healthy donors. The results are expressed as mean \pm SEM (A/B: $n=4)$. *Statistically significant difference from unexposed controls

these experiments were terminated after $5 \mathrm{~h}$ exposure. Generally $n$-Hex-EOM appeared to induce slightly stronger effects on IL- $1 \alpha$, IL-1 $\beta$, COX-2 and CXCL8 mRNAs, while DCM-EOM had somewhat more effect on HO-1 at this time-point (Fig. 6a). CH223191-treatment attenuated IL-1 $\beta$ expression in $n$-Hex-EOM-exposed cells. CXCL8 and HO-1 responses induced by the two lipophilic DEP-EOM fractions were partly reduced by both CH223191 and ENMD-1068. Of interest, ENMD-1068 caused stronger reduction in both $n$-Hex-EOM-induced CXCL8 and HO-1 expression compared to NAC, while the opposite was the case for DCM-EOM-induced effects on these genes. IL- $1 \alpha$, COX-2, MMP- 1 and PAI-2 levels induced by $n$-Hex-EOM were not significantly affected by any of the inhibitors (Fig. 6a). By comparison,
NAC suppressed COX-2 and MMP-1 expression induced by DCM-EOM and CH223191 suppressed both MMP-1 and PAI-2 (Fig. 6b). Furthermore, DCM-EOMinduced PAI-2 was blocked by ENDM-1068. However, as both MMP1 and PAI-2 were only weakly upregulated at this time-point, it was difficult to measure any significant effects of inhibitors. Overall, the data suggest that the AhR (CH223191) and PAR-2 (ENMD1068) are involved in the inflammation-linked responses (IL-1 $\beta$, CXCL- 8 and HO- 1 ) of both $n$-Hex- and DCMEOM. Moreover, IL- $1 \alpha$ expression was not affected by any of the tested inhibitor/antioxidant treatments, which underscores that DEP-induced inflammation could hardly be explained by the few mechanisms explored in the present study. 

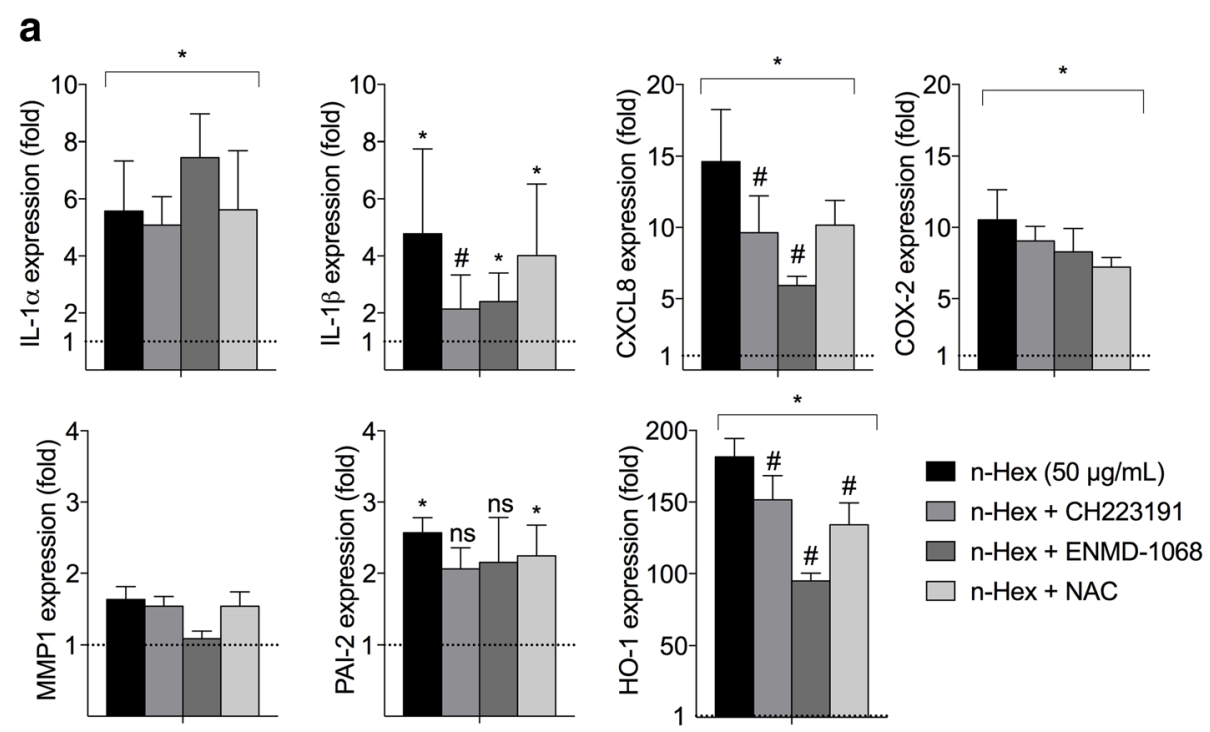

b
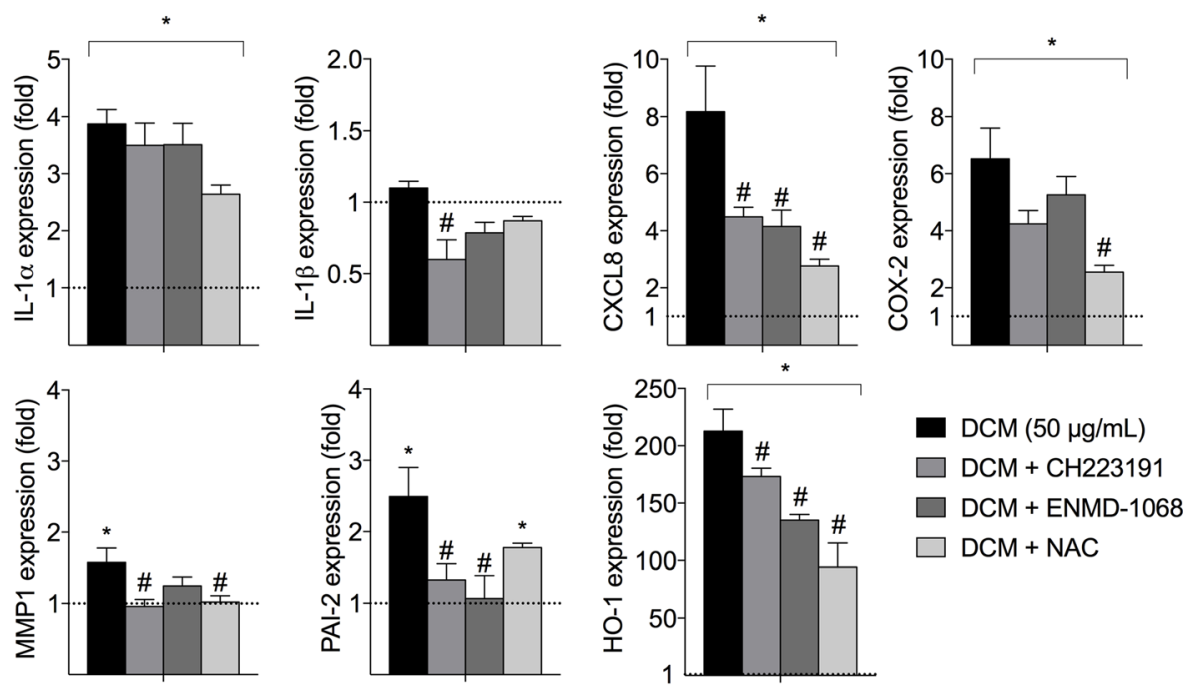

Fig. 6 Effects of inhibitors on DEP-EOM-induced gene expression in HMEC-1. Cells were pre-treated with the anti-oxidant NAC (2 mM), the AhR inhibitor


DEP-EOM at a concentration corresponding to $50 \mu \mathrm{g} / \mathrm{mL}\left(7.5 \mu \mathrm{g} / \mathrm{cm}^{2}\right)$ of native particles, or vehicle (DMSO) alone, for $5 \mathrm{~h}$. Gene expression was measured by $\mathrm{q}-\mathrm{PCR}$. The mRNA levels are presented relative to gene expression in cells exposed to DMSO, represented by the dotted line at 1 . The results are expressed as mean \pm SEM (A/B: $n=3)$. *Statistically significant difference from unexposed controls. \#Statistically significant difference from cells exposed to DEP-EOM

\section{Mechanisms of DEP-EOM-induced gene expression in PHEC}

Finally, we also explored the mechanisms involved in the regulation of the pro-inflammatory responses induced by $n$ Hex- and DCM-EOM in batches of PHECs from one donor. PHECs were pretreated with the AhR- and PAR-2 inhibitors CH223191 (1.0 $\mu \mathrm{M})$ and ENMD-1068 (2.5 mM) for $30 \mathrm{~min}$ prior to 5 or $12 \mathrm{~h}$ exposure with the two lipophilic DEP-EOM fractions at a concentration corresponding to $5 \mu \mathrm{g} / \mathrm{ml}\left(0.75 \mu \mathrm{g} / \mathrm{cm}^{2}\right)$ of original DEP. As no effect was observed on HO-1 expression in PHECs (Fig. 5), effects of NAC were not investigated. Like in HMEC-1 cells, induction of IL- $1 \beta$ by both $n$-Hex- and DCM-EOM was attenuated by $\mathrm{CH} 223191$-treatment to near basal levels (Fig. 7). ENMD-1068 also blocked DCM-EOM-induced IL-1ß. A similar effect of the PAR-2 inhibitor was also observed for $n$-Hex-EOM-induced IL-1 $\beta$, but this reduction was not statistically significant. Furthermore, CH223191, but not ENMD-1068 attenuated both COX-2 and PAI-2 responses in the DCM-EOM-exposed PHECs. Notably, COX-2 expression was not significantly reduced by $\mathrm{CH} 223191$ in $n$ Hex-EOM-exposed cells, but the statistically significant increase in COX-2 was lost in cells treated with the AhRinhibitor. As expected, the induction of CYP1A1 and -1B1 

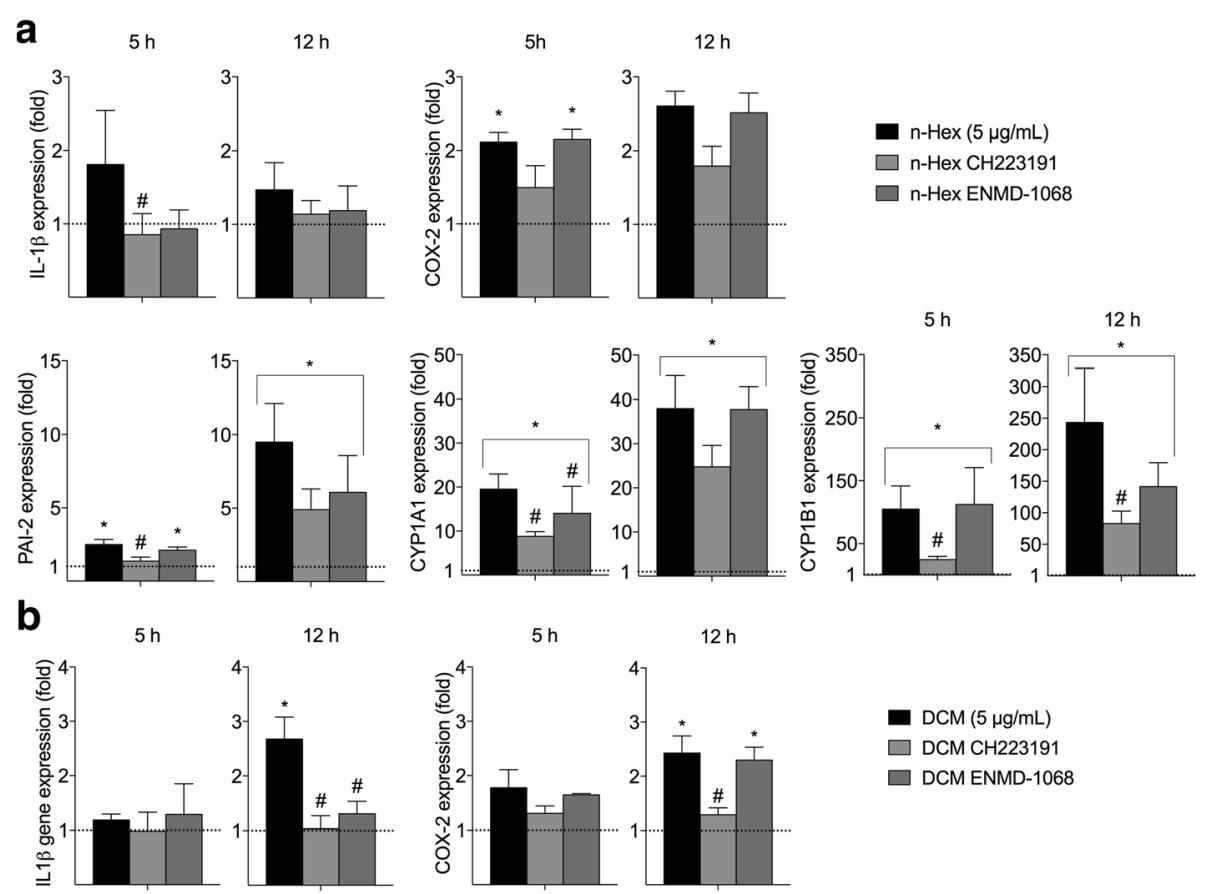

$$
\begin{aligned}
& \text { DCM }(5 \mu \mathrm{g} / \mathrm{mL}) \\
& \square \text { DCM CH223191 } \\
& \text { DCM ENMD-1068 }
\end{aligned}
$$
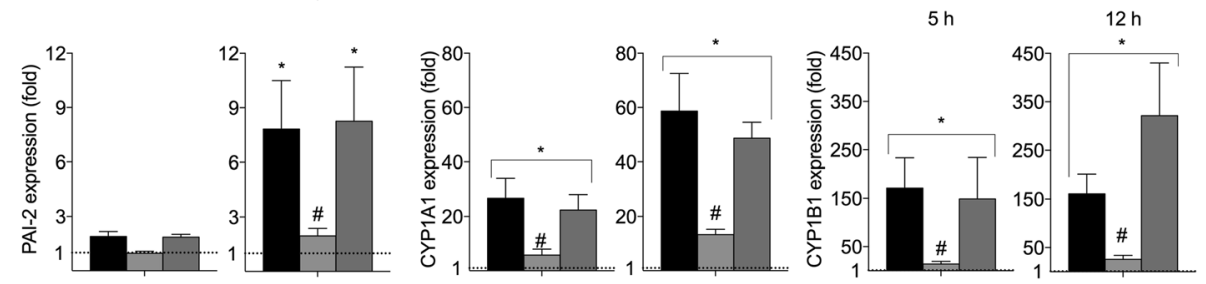

Fig. 7 Effects of inhibitors on DEP-EOM-induced gene expression in PHEC. Cells from one donor were pre-treated with the AhR inhibitor CH223191 (1.0 $\mu \mathrm{M})$, or the PAR-2 inhibitor ENMD-1068 (2.5 mM) for 30 min prior to exposure to the lipophilic $n$-Hexane- (a) or DCM-soluble (b) fractions of DEP-EOM at a concentration corresponding to $5 \mu \mathrm{g} / \mathrm{mL}\left(0.75 \mu \mathrm{g} / \mathrm{cm}^{2}\right)$ of native particles, or vehicle (DMSO) alone, for $5 \mathrm{~h}$. Gene expression was measured by q-PCR. The mRNA levels are presented relative to gene expression in cells exposed to DMSO, represented by the dotted line at 1. The results are expressed as mean $\pm \operatorname{SEM}(5 \mathrm{~h} n=3 ; 12 \mathrm{~h} n=4)$. *Statistically significant difference from unexposed controls. \#Statistically significant difference from cells exposed to DEP-EOM

expression was primarily suppressed by $\mathrm{CH} 223191$. However, some effects of ENMD-1068 were observed on $n$-HexEOM-induced CYP1A1 at $5 \mathrm{~h}$. These results suggest that both AhR and PAR-2 signaling are involved in regulation of pro-inflammatory responses for these relatively low-level exposures of lipophilic and semi-lipophilic DEP-EOM fractions.

\section{Discussion}

Recent findings from ApoE -/- mice suggest that atherosclerotic effects of $\mathrm{PM}_{2.5}$ is due to semi-volatile $\mathrm{OC}$ attached to the particles [47]. In line with this, the present study shows that DEP trigger pro-inflammatory responses in endothelial cells through release of lipophilic OC that could transfer across alveolar epithelial cells. These responses were triggered at concentrations down to exposure-relevant levels and appeared partly dependent on AhR, PAR-2 and (at least at higher concentrations) redox-regulated responses.
In this study we found that DEP-exposure increased expression of IL-1 $\alpha$, PAI- 2 and CYP1B1 in cells on the epithelial side of a 3D tri-culture system, in response to concentrations of DEP in the range $0.5-50 \mu \mathrm{g} / \mathrm{mL}$ corresponding to $0.12-12 \mu \mathrm{g} / \mathrm{cm}^{2}$. The lowest exposure concentration with marked biological effects in the 3D tri-culture $\left(0.12 \mu \mathrm{g} / \mathrm{cm}^{2}\right)$ and the DEP-equivalent exposure concentration of EOM in PHEC $\left(0.15 \mu \mathrm{g} / \mathrm{cm}^{2}\right)$ are within the range estimated for alveolar deposition [36]. Most importantly, we found a rapid and marked induction of the same genes as well as COX-2 and MMP-1 in endothelial cells located on the basolateral side. The AhR marker genes PAI-2 and CYP1B1 [28, 45] were also increased in the endothelial cells, indicating that organic compounds of DEP containing AhRagonists reached the endothelial cells after exposure of the epithelial cells at the apical side. PAI-2 is seemingly regulated via AhR non-canonical signaling [45], and its upregulation indicates that additional pathways to the 
AhR-ARNT pathway is activated. Of notice, results obtained by the use of $10 \mathrm{~nm}$ silica-nanoparticles at fairly high concentrations (SiNP, used as reactive controlparticles without soluble constituents), suggest that DEP-induced effects in the basolateral endothelial cell layer were not due to translocation of particles from the apical compartment, nor to release of pro-inflammatory mediators by the alveolar epithelial cells. Thus, organic compounds most likely detach from DEP and translocate trough the epithelial layer and into the endothelial cells, triggering inflammatory reactions in the microvasculature. A recent study exposing a comparable tetra-culture system of the alveolar-capillary barrier to the standard DEP NIST SRM2975 did not result in any effects on pro-inflammatory genes, and only modest increases in CYP1A1 and Nrf2 in the basolateral endothelial cells [38]. This lack of effect is most likely due to the very low OC-concentration (2\%) in SRM 2975, which thus corroborates our suggestion of a central role of soluble OC in the inflammogenic effects from this DEP and other more OC-rich DEPs. Earlier findings using PAH-rich butadiene soot, have shown that PAHs are transferred from the particle surface to the cell membrane and enters the cytosol of lung epithelial cells, without particle uptake [22]. Based on these findings and our present results we suggest that lipophilic chemicals from DEP deposited in the alveoli, could reach the microvascular endothelium, by transfer through the lipid-rich membranes of alveolar epithelial cells. Moreover, in vivo studies with PAHcoated carbon particles have shown that much of the PAHs are rapidly transferred into the circulation in an un-metabolized state [23], and likely transported by low density lipoproteins from the lungs to cells of the artery wall [48-50]. In fact, PAH-adducts have been detected in atherosclerotic plaques, and $\mathrm{PAH}$-exposure induce endothelial inflammation and progression of atherogenesis [51, 52].

The majority of the observed effects of DEP appeared to be due to lipophilic and semi-lipophilic compounds extractable by $n$-hexane and DCM. These two DEP-EOM also contained most of the extractable OC. The highest concentrations of the methanol fraction, containing more water-soluble compounds, induced PAI-2, CYP1A1, CYP1B1 and cytokines slightly. This could be caused by small amounts of lipophilic OC left by the two preceding extractions. On the other hand, hydrophilic OC from DEP has been reported to affect CYP-expression [53]. Nevertheless, the two hydrophilic extracts had negligible effects on expressions of inflammation-associated genes and CYP-enzymes in HMEC-1 and PHEC, compared to the two more lipophilic extracts. This is in line with previous findings by us and others, showing that lipophilic extracts from DEP induced CXCL8 and IL-6 responses in human bronchial BEAS-2B cells $[18,32]$. Interestingly, the majority of volatile/semi-volatile compounds were present in $n$-Hex- and DMC-EOM, in accordance with the findings of Keebaugh et al. [47].

Chronic or repeated low-grade inflammation in the endothelium is considered to contribute to development and exacerbation of endothelial dysfunction and atherosclerosis $[11,14,25,54]$. In line with this, our results show that soluble organic material from DEP may trigger low to moderate increases in several pro-inflammatory genes in the endothelial cells. The important role of IL-1 cytokines in the development of CVD is highlighted by ongoing medical trials investigating IL-1 $\beta$ as therapeutic target in treatment of CVD $[55,56]$. In the 3D tri-culture, HMEC-1 and PHEC, IL-1 cytokines were induced by DEP or DEPEOM. Of special interest, in PHEC we observed marked effects on IL- $1 \alpha$ and IL- $1 \beta$ mRNA expression (3-6 fold) even at the lowest concentration of exposure. COX-2 was the most sensitive inflammation-associated gene in the $3 \mathrm{D}$ tri-culture, HMEC-1 and PHEC. COX-2 is present in inflamed vessels and highly expressed in atherosclerotic lesions; where it can potentially produce large amounts of prostanoids and PGE2. PGE2 can promote the expression of MMPs leading to tissue destruction and destabilization of atherosclerotic plaques [57, 58]. Notably, MMP-1 was induced in HMEC-1 and PHEC as well as the 3D triculture after exposure for $20 \mathrm{~h}$ or more. It is thus tempting to speculate that the induction and release of MMP-1 at $24 \mathrm{~h}$, was caused at least partly through COX-2mediated PGE2 production. Taken together, DEP induced increased endothelial expression of pro-inflammatory genes considered relevant in development and progression of atherosclerosis.

DEP most likely initiates cellular responses through a number of different constituents and multiple triggering mechanisms, and pro-inflammatory effects arise from the combined activation of several pathways. Generally, particles and soluble particle components can trigger inflammatory responses through four central events: (i) formation of ROS, (ii) interaction with the lipid layer of cellular membranes, (iii) activation of receptors, ion channels and transporters on the cell surface, and (iv) interaction with intracellular molecular targets including receptors [26, 59]. In this study we have addressed three of these triggering events: ROS formation, activation of membrane receptors (PAR-2) and the intracellular receptor AhR. These mechanisms are of interest since they have been implicated in the pathogenesis of CVD, most notably through their effects on pro-inflammatory signaling [34, 60-63]. Of notice, the relative impact of inhibitor- and antioxidant-treatment varied considerably with both the type of exposure ( $n$-Hex- or DCM-EOM) and the genes investigated. This suggests that the two lipophilic extracts induce effects at least partly by different constituents and through different pathways, which 
is consistent with the notion that a number of mechanisms are involved in the effects from complex exposures such as DEP.

AhR is a ligand-activated transcription factor with affinity for planar aromatic compounds including several PAHs and dioxins, and is among the most well studied xenobiotic receptors [28]. The vasculature is suggested to be a target of PAH exposure [64-66], and AhRligands have been shown to disrupt endothelial function, causing atherosclerosis, [60, 62]. In the present study AhR seemed to be partly involved in the regulation of DEP-EOM-induced IL-1 $\beta$, CXCL8, MMP- 1 and HO- 1 in HMEC-1. In PHEC the role of AhR in mediating effects of $n$-hexane- and DCM-EOM was similar, CH223191 reduced IL-1 $\beta$ and COX-2. This effect did not seem to be cell-line dependent. AhR could potentially regulate proinflammatory genes such as IL- $1 \beta$ and CXCL- 8 through cross-talk with the nuclear factor- $\mathrm{kB}(\mathrm{NF}-\mathrm{\kappa} \mathrm{B})$ family of transcription factors or through binding to AhRresponse elements (XREs) in their promoter region [29, 30, 67]. However, the effect of AhR-inhibition on COX-2 expression, could also be related to non-genomic signaling [68]. Furthermore, it has been found that AhR ligands induce MMP-1 in human bronchial cells [69], the observed effects on MMP-1 could thus be related to AhR activation. Most importantly, these results indicate that AhR-ligands contribute to the pro-inflammatory effects from lipophilic DEP-EOM in endothelial cells.

G-coupled receptors including PAR are central in endothelial inflammatory responses [33, 34], and PAR-2 has been reported to regulate MMP-1 in bronchial epithelial cells exposed to DEP [17]. Inhibiting PAR-2 with ENMD1068 caused marked reductions of CXCL8, HO-1 and PAI-2 in HMEC-1. Interestingly, PAR-2 inhibition reduced the effect of the $n$-hexane extract on CXCL8 and HO-1 more markedly than NAC. Thus CXCL8, HO-1 and PAI-2 expression in HMEC-1 seem to be linked to PAR-2regulated pathways. In PHEC it seemed that PAR-2 partially regulated IL-1 $\beta$ and CYP1A1 (Fig. 6). We have previously found that DEP-induced IL-6 was reduced by PAR-2 silencing in BEAS-2B [32]. Taken together, it seems that PAR-2 contributes to the signaling pathways mediating inflammatory effects of DEP in both bronchial and endothelial cells. PAR-2 is activated by protease-mediated cleavage of the n-terminal domain [33, 34]. Unless DEP and DEPEOM contains protease activity, it seems more likely that PAR-2 is not directly targeted by the particles or particle components, but rather trans-activated in response to some upstream triggering mechanism. As both PAR-2 and AhR could initiate calcium signaling [17, 68], and since AhR is known to interact with a number of different cellular pathways [70], it is tempting to speculate that there could be a link between signaling from these two receptors in DEP-exposed cells.
The oxidative stress paradigm has dominated the understanding of how DEP and other particulates trigger inflammatory responses in various cell types $[36,71]$. In HMEC- 1 only the highest concentrations of $n$-Hex- and DCM-EOM induced HO-1. The DCM extract induced the strongest increase in $\mathrm{HO}-1$ expression, at least at later time-points, and the suppressive effects of NAC was most pronounced in DCM-EOM-exposed cells. This correlates well with previous findings that the mid-polar and nonpolar OC of wood smoke PM caused GSH depletion in RAW 264.7 macrophages [72] and the notion that DCM have higher levels of redox reactive OC than $n$-hexane [41]. Of all the genes investigated, CXCL8 expression appeared to be most closely associated with HO-1 expression, indicating a central role of redox-regulation. However, while HO-1, CXCL8 and COX-2 gene expressions were partially reduced by NAC, IL- $1 \alpha$, IL- $1 \beta$ and PAI-2 appeared to be unaffected by the antioxidant treatment. Moreover, at the lowest concentrations tested in HMEC-1 and PHEC cells, as well as the tri-culture, proinflammatory gene expression appeared to be induced in the absence of effects on HO-1 expression. Thus, our results indicate that the role of oxidative stress in regulation of DEP-induced pro-inflammatory responses could be a high-dose phenomenon. By contrast, DEP- and DEPEOM-induced gene expression at the lowest concentrations tested appeared to be triggered through receptormediated effects in absence of oxidative stress. While our present data clearly are insufficient to conclude on this matter, they highlight the importance of exploring the role of redox-responses and oxidative stress at exposurerelevant DEP-concentrations [36].

\section{Conclusion}

This study shows that exposure-relevant concentrations of DEP (from $0.12 \mu \mathrm{g} / \mathrm{cm}^{2}$ ) on the epithelial side of a 3D tri-culture, mimicking the alveolar-capillary barrier, induced increased expression of pro-inflammatory and AhR-regulated genes in the basolateral endothelial cells. These effects were most likely due to soluble organic constituents detached from DEP. Furthermore, direct exposure of HMEC-1 and PHEC to lipophilic organic extracts of DEP induced a comparable up-regulation of pro-inflammatory and AhR-regulated genes, most notably at low concentrations in PHEC $\left(0.15 \mu \mathrm{g} / \mathrm{cm}^{2}\right)$. These effects appeared to be linked to AhR and PAR-2 signaling, and at higher concentrations also involved redox-regulated responses. Thus AhR agonists and other lipophilic constituents appear to be the main drivers of these effects. Although further studies will be necessary to validate these findings, we suggest that lipophilic organic compounds from DEP may cross over the alveolar epithelium triggering inflammatory reactions in remote endothelial cells. 


\section{Methods}

\section{Chemicals}

Benzo $[a]$ pyrene $(\mathrm{B}[a] \mathrm{P})$, dimethyl sulfoxide (DMSO) and hydrocortisone were purchased from Sigma-Aldrich (St. Louis, MO). All organic solvents were of $>99 \%$ purity (GC or LC-MS grade) and purchased from VWR (Radnor, PA, USA). Analytical standards were obtained from either Fisher Scientific (Hampton, NH, USA) or SigmaAldrich (St. Louis, MO, USA). Phorbol-12-myristate-13acetate (PMA) was purchased from Merck KGaA (Darmstadt, Germany); L-Glutamine (200 mM) from Thermo Fischer Scientific (Scotland); endothelial growth factor from Nerliens Meszansky (Oslo, Norway); penicillin and streptomycin and EC growth medium (EGM2MV) from Lonza (Walkersville, MD, USA); and MCDB 131, RPMI-1640 and DMEM medium with Glutamax was provided by Life TechnologiesTechnologies (NY, USA); fetal calf serum (FCS) from Biochrom AG (Berlin, Germany). The suspensions of silica nanoparticles with nominal size of $10 \mathrm{~nm}$ (SiNP) was purchased from Kisker Biotech (Steinfurt, Germany).

RNA isolation done with RNeasy from Qiagen (Qiagen, Germantown, MD) or NucleoSpin RNA Plus (MachereyNagel; Düren, Germany). All real-time Real Time/quantitative-PCR (q-PCR) reagents and TaqMan probes/primers were purchased from Applied Biosystems (Foster City, CA, USA). Cytokine ELISA assays for IL-6 (Human IL-6 CytoSet) and CXCL8 (Human IL-8 CytoSet) were purchased from Biosource International (Camarillo, CA, USA). ELISA assays for MMP-1 were purchased from R\&D systems (Minneapolis MN, USA). Cell culture flasks were obtained from Nunc A/S (Roskilde, Denmark) and 12-well plates from Corning, Lowell (MA, USA). The Falcon transwell inserts and additional 6-well TC-Treated Polystyren plate Companion were purchased from Corning (surface area of $4.2 \mathrm{~cm}^{2} ; 1 \mu \mathrm{m}$ pore size; high pore density PET membranes; BD Biosciences, Basel, Switzerland).

Diesel exhaust particles, chemical extraction and analysis DEP currently used were collected from the tail-pipe of a diesel engine (Deutz, 4 cylinder, 2.2 1, $500 \mathrm{rpm}$ ) running on gas oil,characterized as described elsewhere [40, 41], and kindly provided by Flemming R. Cassee (RIVM). These particles contain approximately $60 \%$ OC, corresponding to other OC-rich DEP $[73,74]$. Although the current DEP is not necessarily representative of DEP from modern cars, the PAH-composition of these particles resembles what has been reported from other DEPs, with high levels of phenanthrene, fluoranthene, pyrene and chrysene [41, 42]. The detailed approach to characterization of extracts is provided below.

Extraction: DEP extraction was performed with a series of solvents ranging from non-polar to polar using a pressurized extraction system as previously described [75].
The DEP-EOM (10 mg) was extracted separately by a solvent sequence of increasing polarity, from n-hexane to water. Organic solvents were employed using a dynamic mode at constant flow of $0.5 \mathrm{~mL} / \mathrm{min}$ for $30 \mathrm{~min}$ through the extraction vessel. The final water fraction was obtained using first a static mode, where solvent remained in contact with the DEP sample for $5 \mathrm{~min}$, followed by a dynamic extract collection at a flow rate of $0.6 \mathrm{~mL} / \mathrm{min}$ for 5 min (i.e., a flushing volume of $3.0 \mathrm{~mL}$, more than three internal extraction vessel volumes). Each DEP-EOM fraction was analyzed as described below:

Chemical Analysis: The $\mathrm{OC}$ in extracts and the original PM was determined using a thermal optical analyzer (Sunset Laboratories, Tigard, OR, USA). The temperature program began with five steps under an inert helium starting at $300{ }^{\circ} \mathrm{C}$, followed by $500{ }^{\circ} \mathrm{C}, 600{ }^{\circ} \mathrm{C}, 700{ }^{\circ} \mathrm{C}$ each step for $75 \mathrm{~s}$, and $870{ }^{\circ} \mathrm{C}$ for $120 \mathrm{~s}$. Then, the instrument was cooled down to $550{ }^{\circ} \mathrm{C}$ and helium with $5 \%$ oxygen was introduced with the temperature program starting with $550{ }^{\circ} \mathrm{C}$ for $45 \mathrm{~s}$, $625{ }^{\circ} \mathrm{C}$ for $45 \mathrm{~s}, 700{ }^{\circ} \mathrm{C}$ for $45 \mathrm{~s}$, and $890{ }^{\circ} \mathrm{C}$ for $120 \mathrm{~s}$. For OC analysis $50-150 \mu \mathrm{g}$ of PM was placed onto pre-baked quartz filter $\left(600{ }^{\circ} \mathrm{C}\right.$, overnight) using a glass rod. DEPEOM fractions were analyzed by introducing an aliquot $(10-80 \mu \mathrm{L})$ on the pre-baked quartz filter placed on a heating plate. The solvent was then evaporated at $45^{\circ} \mathrm{C}$ for $4-$ $8 \mathrm{~min}$, depending on the type of solvent [73]. To distinguish pyrolyzed OC from EC, laser transmittance at $658 \mathrm{~nm}$ was used. As expected no EC was found in the extracts.

The gas chromatography mass spectrometry (GC-MS) revealed only alkanes, PAHs and PAHs derivatives in the extracts. The corresponding aliquots in organic solvents were spiked with deuterated recovery standards (naphthalene-d8, pyrene-d10, and 1-hydroxypyrene-d9) and concentrated to $200 \mu \mathrm{L}$ under a gentle stream of nitrogen. Water aliquots were also spiked with recovery standards, but concentrated to $200 \mu \mathrm{L}$ using a vacuum rotary evaporator $\left(7-20 \times 10-3\right.$ bar, $\left.30{ }^{\circ} \mathrm{C}\right)$. Half of the concentrated sample $(100 \mu \mathrm{L})$ was then spiked with an internal standard (fluoranthene-d10) and analyzed directly using a gas chromatograph coupled to mass spectrometer (GC-MS). To determine hydroxy-PAHs, the other half of the concentrated sample $(100 \mu \mathrm{L})$ was evaporated to dryness under gentle stream of nitrogen and mixed with $50 \mu \mathrm{L}$ of sialylation agent, BSTFA. The mixture was then heated for $10 \mathrm{~h}$ at $70{ }^{\circ} \mathrm{C}$, mixed with $50 \mu \mathrm{L}$ of dichloromethane, and with fluoranthene-d10.

The GC-MS used was a 6890 Series II Plus GC coupled to a 5975C MS detector (Agilent, Santa Clara, CA). Separations were carried out using a $22 \mathrm{~m}$-long DB-5MS column with $0.25 \mathrm{~mm}$ internal diameter and 0 . $25 \mathrm{~mm}$ film thickness (J\&W Scientific, Rancho Cordova, CA, USA) at a constant helium flow rate of $1.0 \mathrm{~mL} / \mathrm{min}$. Samples $(1.0 \mu \mathrm{L})$ were injected in a splitless mode for 0 . $5 \mathrm{~min}$ at $250{ }^{\circ} \mathrm{C}$. The temperature program started at 
$35{ }^{\circ} \mathrm{C}$ that was held for $2 \mathrm{~min}$, followed by an increase to $140{ }^{\circ} \mathrm{C}$ with a $15{ }^{\circ} \mathrm{C} / \mathrm{min}$ temperature gradient. The last step was an increase to $320{ }^{\circ} \mathrm{C}$ with a $10{ }^{\circ} \mathrm{C} / \mathrm{min}$ temperature gradient, held for $10 \mathrm{~min}$. The total run time was $37 \mathrm{~min}$. The transfer line temperature was set to $280{ }^{\circ} \mathrm{C}$. The MS data were acquired in the full scan mass range of $43-500 \mathrm{~m} / \mathrm{z}$ using an electron ionization $(70 \mathrm{eV})$. Quantifications were done using eight-point calibrations with the corresponding standard quantification ions listed in Additional file 1: Table S1. For compounds for which standard were not available the nearest isomeric standard was employed.

\section{Particle size and distribution}

The dynamic size measurements were performed at $37^{\circ} \mathrm{C}$ in the culture media used in the study, at a concentration of $50 \mu \mathrm{g} / \mathrm{ml}$. Each particle solution was measured 3 times on a zeta-sizer NANO ZSP (Malvern Instruments Ltd., WR14 1XZ, UK). The results are presented as mean size distribution by intensity. The DEP had a bimodal distribution, with a minor peak around $100 \mathrm{~nm}$ and the main peak around $300 \mathrm{~nm}$. As nucleation mode DEP typically is less than $40-50 \mathrm{~nm}$ in diameter [15], it seems likely that both peaks could represent agglomerated particles. Interestingly, the $10 \mathrm{~nm}$ SiNPs displayed a comparable distribution, peaking around 200-300 nm, suggesting that also these particles primarily occurred as agglomerates when suspended in media (Additional file 1: Figure S6).

\section{Cell cultures}

A 3D tri-culture consisting of three different cell-types, EA-hy926, A549 and PMA-differentiated THP-1 cells, were prepared principally as described by Klein and coworkers [38]. The cells were obtained from the American Type Culture Collection (Manassas, VA, USA). EA. hy 926, A549 and THP-1 cells were maintained in either DMEM with Glutamax, 10\% FCS and 1\% Hepes (Ea.hy 926 and A549) or in RPMI-1640 with 10\% FCS (THP-1) in T75 flasks in a humidified atmosphere at $37{ }^{\circ} \mathrm{C}$ with $5 \% \mathrm{CO}_{2}$, with refreshment of medium twice a week.

Building the 3D tri-cultures started by seeding EA.hy $926 \mathrm{EC}$ on the inverted trans-well inserts at a density of $2.57 \times 10^{5}$ cells $/ \mathrm{cm}^{2}$. Four $\mathrm{h}$ after seeding, the plate with the trans-well inserts was turned back to its original orientation and A549 cells were seeded inside the transwell $\left(1.28 \times 10^{5}\right.$ cells $\left./ \mathrm{cm}^{2}\right)$. Epithelial and endothelial cells were then grown for 3 days at $37{ }^{\circ} \mathrm{C}$ and $5 \%$ in a humidified incubator with $2 \mathrm{~mL}$ of DMEM with Glutamax, 10\% FCS and 1\% Hepes in the upper and lower chamber; then for 1 day with co-culture media (DMEM with Glutamax and 15\% RPMI-1640, 10\% FCS and $1 \%$ Hepes).On day 3, THP-1 cells were differentiated into macrophage-like cells with PMA $(20 \mathrm{ng} / \mathrm{mL}$; PMAdifferentiated THP-1 cells). On day 4, differentiated
THP-1 cells $\left(2.57 \times 10^{5}\right.$ cells $\left./ \mathrm{cm}^{2}\right)$ were added to the inserts and the complete tri-culture was kept in coculture media with $1 \%$ FCS. On day 5 the $3 \mathrm{D}$ tricultures were ready for exposures.

Ea. Hy 926 monocultures were seeded on 6 well plates at a cell density of 250.000 cells/well in $1.5 \mathrm{ml}$ of DMEM with Glutamax, 10\% FCS and 1\% Hepes 2 days before exposure.

Human micro-vascular endothelial cells (HMEC-1), obtained from Laboratory of the Government Chemist (LGC Standards, Germany), were routinely maintained in MDCB131 medium containing epidermal growth factor $(10 \mathrm{ng} / \mathrm{mL})$, hydrocortisone $(0.2 \mu \mathrm{g} / \mathrm{mL})$, penicillin (50 unit/mL), and streptomycin $(50 \mu \mathrm{g} / \mathrm{mL})$ and supplemented with $10 \%$ fetal calf serum (FCS), according to the providers instructions.

Primary human endothelial cells (PHEC) were isolated from adipose tissue obtained from liposuction material from abdominal regions of four healthy female donors (aged 22-35 years; BMI: 23-30) undergoing cosmetic surgery [76]. The stromal vascular fraction was isolated as described previously [76]. Briefly, lipo-aspirates were washed and digested using $0.1 \%$ collagenase A type 1 . After centrifugation, the cell pellet was filtered through $100 \mu \mathrm{m}$ and then $40 \mu \mathrm{m}$ cell sieves. Cells were obtained from the interface after Lymphoprep gradient separation (Axis Shield; Oslo, Norway). CD44+ cells were removed using Dynabeads (Dynabeads Pan Mouse IgG; Invitrogen Dynal AS, Oslo, Norway) according to the manufacturer's description. PHEC were plated at $2 \times 10^{6}$ cells per $75-\mathrm{cm}^{2}$ tissue culture flask Nunc A/S (Roskilde, Denmark). Cells were maintained at $37{ }^{\circ} \mathrm{C}$ in an atmosphere of $5 \% \mathrm{CO}_{2}$ in humid air using endothelial cell growth medium (EGM$2 \mathrm{MV}$ ) with supplements according to the manufacturer's description; human AB-serum (serum from individuals with blood-type $A B$ ) was used instead of FCS. Cells were routinely passaged every 3-4 days.

\section{In vitro exposures}

$3 D$ tri-culture: prior to exposure, the media was changed to co-culture media without FCS. DEP suspended in coculture media without FCS were added to the upper chamber. After 2 or $20 \mathrm{~h}$ exposure, cells from the apical compartment (A549 and PMA-differentiated THP-1 cells) and the basolateral compartment (EAhy.926 endothelial cells) were harvested and mRNA was isolated using the RNeasy mini kit according to the protocol from the manufacturer (Qiagen, Germantown, MD). In separate experiments the tri-culture and EAhy.926 endothelial cells were exposed to Si10 in absence of FCS for 3 and $6 \mathrm{~h}$ prior to harvesting of mRNA.

HMEC-1 and PHEC were grown to near-confluency and serum-starved for a minimum of $12 \mathrm{~h}$ prior to exposure. Cells were then exposed by removing the media and adding growth medium without FCS containing 
various DEP-EOM suspended in DMSO or DMSO alone. After 2, 5 or $24 \mathrm{~h}$ exposure, growth-medium was obtained for ELISA, cells were harvested and mRNA extracted. In all experiments that included chemical inhibitors, cells were pre-treated for 30 min with the inhibitor, then exposed to the DEP-EOM.

Chemicals were commonly prepared as stock solution in DMSO. The final concentration of solvent did not exceed $0.2 \%(v / v)$; control cultures received similar concentration of DMSO. Stock solution of Si10 was dispersed in sterile water $(2.3 \mathrm{mg} / \mathrm{ml})$ and sonicated for approximately $2 \mathrm{~min}$ on ice (until specific ultrasound energy of $420 \mathrm{~J}$ was given to the nanoparticles). Bovine serum albumin (BSA, final concentration 0.15\%) and phosphate buffered saline (PBS, final dilution $1 \times$ ) were then added to the particle solution, according to the method by Bihari and co-workers [77].

\section{Gene expression analysis by real-time RT-PCR}

RNA was isolated using NucleoSpin RNA Plus (MachereyNagel; Düren, Germany) or RNeasy from Qiagen (Qiagen, Germantown, MD), and reverse transcribed to cDNA on a PCR System 2400 (PerkinElmer, Waltham, MA, USA) using a High Capacity cDNA Archive Kit (Applied Biosystems, Foster City, CA, USA). Real-time PCR was performed using pre-designed TaqMan Gene Expression Assays and TaqMan Universal PCR Master Mix and run on Applied Biosystems 7500 fast software. Gene expression of induced IL-1 $\alpha$ (Hs00174092_m1), IL-1 $\beta$ (Hs01555410_m1), IL-6 (Hs00174131_m1), CXCL8 (Hs00174103_m1), COX-2 (Hs00153133_m1), MMP-1 (Hs00899658_m1), HO1(Hs01110250_m1), PAI-2/SERPINB2 (Hs01010736_m1), CYP1A1 (Hs00153120_m1) and Cyp1B1 (Hs02382916_s1) were normalized against GAPDH (Hs02758991_g1) and expressed as fold change compared to untreated control as calculated by the $\Delta \Delta \mathrm{Ct}$ method $(\Delta \mathrm{Ct}=\mathrm{Ct}$ [Gene of Interest] - Ct[18S]; $\Delta \Delta \mathrm{Ct}=\Delta \mathrm{Ct}[$ Treated $]-\Delta \mathrm{Ct}[$ Control $]$; Fold change $=2[-\Delta \Delta \mathrm{Ct}])$.

\section{ELISA}

The amount of MMP-1, IL-6 and CXCL8 in cell medium was measured by ELISA according to the manufacturers' guideline. An increase in color intensity was quantified by a plate reader (TECAN Sunrise, Phoenix Research Products, Hayward, CA, USA) equipped with a dedicated software (Magellan V I.10; Tecan Austria GmbH, Grödig-Salzburg, Austria).

\section{Flow cytometry}

Flow cytometry was performed for determination of cell surface antigen expression of PHEC from one donor as described previously [46]. Cells were analyzed using a Gallios flow cytometer from Beckman Coulter with Gallios software.

\section{Statistical analysis}

Statistical analysis was performed by ANOVA with Holm-Sidak post-test for multiple comparisons. As ANOVA cannot be performed on normalized data, the gene expression data were analyzed using the deltaCTvalues from the q-PCR measurements. All calculations were performed using GraphPad Prism 7 software (GraphPad Software, Inc., San Diego, CA).

\section{Additional file}

Additional file 1: Figure S1. In a 3D tri-culture, exposure to SiNP on the epithelial side, induced COX-2 on the epithelial side, but not in the endothelial cells. Furthermore EAhy.926 endothelial cells exposed directly to SiNP up-regulated COX-2. Figure S2. The amount of volatile/semivolatile compounds extracted decreased according to polarity of the solvents. Figure S3. Cytotoxicity of DEP-EOM in HMEC-1 and PHEC. Figure S4. Lipophilic DEP-EOMs cause CXCL8 secretion in HMEC-1 cells. Figure S5. PHEC were 99\% CD31-positive. Figure S6 Size distribution, DEP and SiNP. Table S1. GC-MS quantified compounds with corresponding MS ions and calibration standards. (DOCX $2036 \mathrm{~kb}$ )

\section{Abbreviations}

AhR: Aryl hydrocarbon receptor; B[a]P: Benzo[a]pyrene; CH223191: AhRinhibitor; CVD: Cardiovascular disease; CYP: Cytochrome P450; DCMEOM: Organic material of DEP extracted by: Dichloromethane; DEP: Diesel exhaust particles; DEP-EOM: Extractable organic material of DEP; DMSO: Dimethyl sulfoxide; ENMD-1068: PAR-2-inhibitor; HMEC-1: Human microvascular endothelial cells; HO-1: Heme oxygenase-1; IL: Interleukin; Methanol-EOM: Organic material of DEP extracted by: Methanol; MMP1: Matrix metalloproteinase-1; MW: Molecular weight; NAC: N-acetylcysteine; NF-kB: Nuclear factor-kB; $n$-Hex-EOM: Organic material of DEP extracted by: n-hexane; OC: Organic chemicals; PAHs: Polycyclic aromatic hydrocarbons; PAI-2: Plasminogen activator inhibitor 2; PAR-2: Protease-activated receptor-2; PHEC: Primary human endothelial cells; PM: Particulate matter; PM $2.5_{\text {: Fine }}$ traffic-derived PM; PMA: Phorbol-12-myristate-13-acetate; ROS: Reactive oxygen species; $\mathrm{SiNP}: \mathrm{SiO}_{2}$ nanoparticles; Water-EOM: Organic material of DEP extracted by: Water at $25^{\circ} \mathrm{C}$; XREs: AhR-response elements

\section{Acknowledgements}

We thank E. Lilleaas and HJ. Dahlman (Norwegian Inst. of Public Health, Oslo, Norway) for technical assistance throughout the study. The contribution of EM and ACG was performed in the framework of the internally funded "In vitro models for the prediction of respiratory irritation and sensitization IMPERIS" project (LIST). BC Brinchmann was supported by a travel exchange grant from Rennes Métropole, to realize part of his PhD in Rennes, France. The work at NIPH, including two travel grants were supported by the Research Council of Norway, through the Environmental Exposures and Health Outcomes-program (grant no. 228143).

\section{Funding}

The contribution of EM and ACG was performed in the framework of the internally funded "In vitro models for the prediction of respiratory irritation and sensitization - IMPERIS" project (LIST). BC Brinchmann was supported by a travel exchange grant from Rennes Métropole, to realize part of his PhD in Rennes, France. The work at NIPH, including two travel grants were

supported by the Research Council of Norway, through the Environmental Exposures and Health Outcomes-program (grant no. 228143).

\section{Availability of data and materials}

The datasets used and/or analyzed during the current study are available from the corresponding author on reasonable request.

\section{Authors' contributions}

$\mathrm{BB}$ performed all HMEC-1 and PHEC experiments, and contributed in all experimental planning and design in collaboration with $\lrcorner \varnothing$ and JAH. TS, EM performed the 3D tri-culture experiments. BB, TS and $J \varnothing$ performed 
the data analysis and statistics. PHEC were isolated and cultivated by KZ and MHR. KK and AK performed the OC-extraction and chemical characterization. $J \varnothing$ conceived and coordinated the study, with support of JAH. BB and JAH drafted the first versions of the manuscript and wrote the final version in collaboration with $\rfloor \varnothing$. All authors read, commented and approved the final manuscript.

\section{Competing interests}

The authors report no competing interests. The authors alone are responsible for the content and writing of the paper.

\section{Publisher's Note}

Springer Nature remains neutral with regard to jurisdictional claims in published maps and institutional affiliations.

\section{Author details}

'Department of Air Pollution and Noise, Domain of Infection Control, Environment and Health, Norwegian Institute of Public Health, PO Box 4404, Nydalen, N-0403 Oslo, Norway. ${ }^{2}$ Division of Laboratory Medicine, Faculty of Medicine, University of Oslo, Oslo, Norway. ${ }^{3}$ Norwegian Center for Stem Cell Research, Department of Immunology, Oslo University Hospital, Oslo, Norway. ${ }^{4}$ Luxembourg Institute of Science and Technology (LIST), Environmental Research and Innovation (ERIN) Department, Belvaux, Grand Duchy of Luxembourg. ${ }^{5}$ Department of Chemistry, University of North Dakota, Grand Forks, ND, USA. ${ }^{6}$ Inserm U1085, Institut de Recherche en Santé, Environnement, Travail (IRSET), Rennes, France. ${ }^{7}$ Université de Rennes 1, Faculté des Sciences pharmaceutiques et biologiques, Rennes, France.

Received: 29 December 2017 Accepted: 1 May 2018

Published online: 11 May 2018

\section{References}

1. WHO. Ambient air pollution: a global assesment of exposure and burden of disease. Geneva: World Health Organization; 2016.

2. HEI. STATE OF GLOBAL AiR /2017. Boston: Health Effects Institute and The Institute for Health Metrics and Evaluation; 2017.

3. Brook RD, Rajagopalan S, Pope CA 3rd, Brook JR, Bhatnagar A, Diez-Roux AV, et al. Particulate matter air pollution and cardiovascular disease: an update to the scientific statement from the American Heart Association. Circulation. 2010;121(21):2331-78. https://doi.org/10.1161/CIR.0b013e3181dbece1. https://www.ncbi.nlm.nih.gov/pubmed/20458016

4. Moller P, Mikkelsen L, Vesterdal LK, Folkmann JK, Forchhammer L, Roursgaard M, et al. Hazard identification of particulate matter on vasomotor dysfunction and progression of atherosclerosis. Crit Rev Toxicol. 2011;41(4):339-68. https://doi.org/10.3109/10408444.2010.533152. http://www.ncbi.nlm.nih.gov/pubmed/21345153

5. Bai $Y$, Sun Q. Fine particulate matter air pollution and atherosclerosis: mechanistic insights. Biochim Biophys Acta. 2016;1860(12):2863-8. https://doi.org/10.1016/j.bbagen.2016.04.030. https://www.ncbi.n/m.nih.gov/ pubmed/27156486

6. Siponen T, Yli-Tuomi T, Aurela M, Dufva H, Hillamo R, Hirvonen MR, et al. Source-specific fine particulate air pollution and systemic inflammation in ischaemic heart disease patients. Occup Environ Med. 2015;72(4):277-83. https://doi.org/10.1136/oemed-2014-102240. https://www.ncbi.nlm.nih.gov/ pubmed/25479755

7. Schneider A, Neas LM, Graff DW, Herbst MC, Cascio WE, Schmitt MT, et al. Association of cardiac and vascular changes with ambient PM2.5 in diabetic individuals. Part Fibre Toxicol. 2010;7:14. https://doi.org/10.1186/1743-8977-7-14.

8. Pope CA, Bhatnagar A, McCracken JP, Abplanalp W, Conklin DJ, O'Toole T. Exposure to fine particulate air pollution is associated with endothelial injury and systemic inflammation. Circ Res. 2016;119(11):1204-14. https:// doi.org/10.1161/CIRCRESAHA.116.309279. https://www.ncbi.nlm.nih.gov/ pubmed/27780829

9. McLaren JE, Michael DR, Ashlin TG, Ramji DP. Cytokines, macrophage lipid metabolism and foam cells: implications for cardiovascular disease therapy. Prog Lipid Res. 2011;50(4):331-47. https://doi.org/10.1016/j.plipres.2011.04. 002. https://www.ncbi.nlm.nih.gov/pubmed/21601592

10. van der Vorst EP, Doring $Y$, Weber $C$. Chemokines and their receptors in atherosclerosis. J Mol Med (Berl). 2015;93(9):963-71. https://doi.org/10.1007/ s00109-015-1317-8. https://www.ncbi.nlm.nih.gov/pubmed/26175090
11. Ramji DP, Davies TS. Cytokines in atherosclerosis: key players in all stages of disease and promising therapeutic targets. Cytokine Growth Factor Rev. 2015; 26(6):673-85. https://doi.org/10.1016/j.cytogfr.2015.04.003. https://www.ncbi. nlm.nih.gov/pubmed/26005197

12. Cassee FR, Heroux ME, Gerlofs-Nijland ME, Kelly FJ. Particulate matter beyond mass: recent health evidence on the role of fractions, chemical constituents and sources of emission. Inhal Toxicol. 2013;25(14):802-12. https://doi.org/10. 3109/08958378.2013.850127. https://www.ncbi.nlm.nih.gov/pubmed/24304307

13. Grahame TJ, Klemm R, Schlesinger RB. Public health and components of particulate matter: the changing assessment of black carbon. J Air Waste Manag Assoc (1995). 2014;64(6):620-60.

14. Moller P, Christophersen DV, Jacobsen NR, Skovmand A, Gouveia AC, Andersen $\mathrm{MH}$, et al. Atherosclerosis and vasomotor dysfunction in arteries of animals after exposure to combustion-derived particulate matter or nanomaterials. Crit Rev Toxicol. 2016;46(5):437-76. https://doi.org/10.3109/ 10408444.2016.1149451. https://www.ncbi.nlm.nih.gov/pubmed/27028752

15. Lawal AO, Davids LM, Marnewick JL. Diesel exhaust particles and endothelial cells dysfunction: an update. Toxicol in Vitro. 2016;32:92-104. https://doi. org/10.1016/j.tiv.2015.12.015.

16. Totlandsdal Al, Herseth Jl, Bolling AK, Kubatova A, Braun A, Cochran RE, et al. Differential effects of the particle core and organic extract of diesel exhaust particles. Toxicol Lett. 2012;208(3):262-8. https://doi.org/10.1016/j. toxlet.2011.10.025. https://www.ncbi.n/m.nih.gov/pubmed/22100492

17. Li J, Kanju P, Patterson M, Chew WL, Cho SH, Gilmour I, et al. TRPV4mediated calcium influx into human bronchial epithelia upon exposure to diesel exhaust particles. Environ Health Perspect. 2011;119(6):784-93. https://doi.org/10.1289/ehp.1002807.

18. Kawasaki S, Takizawa H, Takami K, Desaki M, Okazaki H, Kasama T, et al. Benzene-extracted components are important for the major activity of diesel exhaust particles: effect on interleukin-8 gene expression in human bronchial epithelial cells. Am J Respir Cell Mol Biol. 2001;24(4):419-26. https://doi.org/10.1165/ajrcmb.24.4.4085.

19. Bonvallot V, Baeza-Squiban A, Baulig A, Brulant S, Boland S, Muzeau F, et al. Organic compounds from diesel exhaust particles elicit a proinflammatory response in human airway epithelial cells and induce cytochrome p450 1A1 expression. Am J Respir Cell Mol Biol. 2001;25(4):515-21.

20. Van Eeden S, Leipsic J, Paul Man SF, Sin DD. The relationship between lung inflammation and cardiovascular disease. Am J Respir Crit Care Med. 2012; 186(1):11-6. https://doi.org/10.1164/rccm.201203-0455PP. https://www.ncbi. nlm.nih.gov/pubmed/22538803

21. Miller MR, Raftis JB, Langrish JP, McLean SG, Samutrtai P, Connell SP, et al. Inhaled nanoparticles accumulate at sites of vascular disease. ACS Nano. 2017;11(5):4542-52. https://doi.org/10.1021/acsnano.6b08551. https://www. ncbi.nlm.nih.gov/pubmed/28443337

22. Penn A, Murphy G, Barker S, Henk W, Penn L. Combustion-derived ultrafine particles transport organic toxicants to target respiratory cells. Environ Health Perspect. 2005;113(8):956-63.

23. Gerde P, Muggenburg BA, Lundborg M, Dahl AR. The rapid alveolar absorption of diesel soot-adsorbed benzo[a]pyrene: bioavailability, metabolism and dosimetry of an inhaled particle-borne carcinogen. Carcinogenesis. 2001;22(5):741-9.

24. Bostrom CE, Gerde P, Hanberg A, Jernstrom B, Johansson C, Kyrklund T, et al. Cancer risk assessment, indicators, and guidelines for polycyclic aromatic hydrocarbons in the ambient air. Environ Health Perspect. 2002;110(Suppl 3):451-88. https://www.ncbi.nlm.nih.gov/pubmed/12060843

25. Tousoulis D, Charakida M, Stefanadis C. Endothelial function and inflammation in coronary artery disease. Postgrad Med J. 2006;84(993):36871. https://www.ncbi.nlm.nih.gov/pubmed/17095716.

26. Ovrevik J, Refsnes M, Lag M, Brinchmann BC, Schwarze PE, Holme JA. Triggering mechanisms and inflammatory effects of combustion exhaust particles with implication for carcinogenesis. Basic Clin Pharmacol Toxicol. 2017;121 Suppl 3:55-62. https://doi.org/10.1111/bcpt.12746.

27. Gutleb AC. Potential of in vitro methods for mechanistic studies of particulate matter-induced cardiopulmonary toxicity. Crit Rev Environ Sci Technol. 2011;41(22):1971-2002. https://doi.org/10.1080/10643389.2010. 495641. https://doi.org/10.1080/10643389.2010.495641

28. Esser C, Rannug A. The aryl hydrocarbon receptor in barrier organ physiology, immunology, and toxicology. Pharmacol Rev. 2015;67(2):259-79. https://doi. org/10.1124/pr.114.009001. http://www.ncbi.n/m.nih.gov/pubmed/25657351

29. Tian Y, Rabson AB, Gallo MA. Ah receptor and NF-kappaB interactions: mechanisms and physiological implications. Chem Biol Interact. 2002; 141(1-2):97-115. 
30. Vogel CF, Matsumura F. A new cross-talk between the aryl hydrocarbon receptor and RelB, a member of the NF-kappaB family. Biochem Pharmacol. 2009;77(4):734-45. https://doi.org/10.1016/j.bcp.2008.09.036. https://www. ncbi.nlm.nih.gov/pubmed/18955032

31. Namazi MR. Cytochrome-P450 enzymes and autoimmunity: expansion of the relationship and introduction of free radicals as the link. J Autoimmune Dis. 2009;6:4. https://doi.org/10.1186/1740-2557-6-4. https://www.ncbi.nIm. nih.gov/pubmed/19555503

32. Bach N, Bolling AK, Brinchmann BC, Totlandsdal Al, Skuland T, Holme JA, et al. Cytokine responses induced by diesel exhaust particles are suppressed by PAR-2 silencing and antioxidant treatment, and driven by polar and nonpolar soluble constituents. Toxicol Lett. 2015;238(2):72-82. https://doi.org/10. 1016/j.toxlet.2015.07.002. http://www.ncbi.n/m.nih.gov/pubmed/26160521

33. Hirano K. The roles of proteinase-activated receptors in the vascular physiology and pathophysiology. Arterioscler Thromb Vasc Biol. 2007;27(1): 27-36. https://doi.org/10.1161/01.ATV.0000251995.73307.2d. https://www. ncbi.nlm.nih.gov/pubmed/17095716

34. Alberelli MA, De Candia E. Functional role of protease activated receptors in vascular biology. Vasc Pharmacol. 2014;62(2):72-81. https://doi.org/10.1016/j. vph.2014.06.001.

35. Oberdorster G, Finkelstein JN. In vitro dosing of cells with poorly soluble particles. Toxicol Sci. 2006;94(2):439. https://doi.org/10.1093/toxsci/kfl099. author reply 40; https://www.ncbi.nlm.nih.gov/pubmed/16952933

36. Li N, Hao M, Phalen RF, Hinds WC, Nel AE. Particulate air pollutants and asthma. A paradigm for the role of oxidative stress in PM-induced adverse health effects. Clin Immunol (Orlando, Fla). 2003;109(3):250-65.

37. Alfaro-Moreno E, Nawrot TS, Vanaudenaerde BM, Hoylaerts MF, Vanoirbeek JA, Nemery B, et al. Co-cultures of multiple cell types mimic pulmonary cell communication in response to urban PM10. Eur Respir J. 2008;32(5):1184-94. https://doi.org/10.1183/09031936.00044008. https:/www.ncbi.nlm.nih.gov/ pubmed/18653652

38. Klein SG, Cambier S, Hennen J, Legay S, Serchi T, Nelissen I, et al. Endothelia responses of the alveolar barrier in vitro in a dose-controlled exposure to diesel exhaust particulate matter. Part fibre Toxicol. 2017;14(1):7. https://doi. org/10.1186/s12989-017-0186-4

39. Klein SG, Serchi T, Hoffmann L, Blomeke B, Gutleb AC. An improved 3D tetraculture system mimicking the cellular organisation at the alveolar barrier to study the potential toxic effects of particles on the lung. Part Fibre Toxicol. 2013;10:31. https://doi.org/10.1186/1743-8977-10-31.

40. Totlandsdal Al, Cassee FR, Schwarze P, Refsnes M, Lag M. Diesel exhaust particles induce CYP1A1 and pro-inflammatory responses via differential pathways in human bronchial epithelial cells. Part Fibre Toxicol. 2010;7:41. https:/doi.org/10.1186/17438977-7-41. https:/muw.ncbi.nlm.nih.gov/pubmed/21162728

41. Totlandsdal Al, Ovrevik J, Cochran RE, Herseth J, Bolling AK, Lag M, et al. The occurrence of polycyclic aromatic hydrocarbons and their derivatives and the proinflammatory potential of fractionated extracts of diesel exhaust and wood smoke particles. J Environ Sci Health A Tox Hazard Subst Environ Eng. 2014;49(4):383-96. https://doi.org/10.1080/10934529.2014.854586. https://www.ncbi.nlm.nih.gov/pubmed/24345236

42. Xia T, Korge P, Weiss JN, Li N, Venkatesen Ml, Sioutas C, et al. Quinones and aromatic chemical compounds in particulate matter induce mitochondrial dysfunction: implications for ultrafine particle toxicity. Environ Health Perspect. 2004;112(14):1347-58

43. Bouis D, Hospers GA, Meijer C, Molema G, Mulder NH. Endothelium in vitro: a review of human vascular endothelial cell lines for blood vessel-related research. Angiogenesis. 2001;4(2):91-102.

44. Ades EW, Candal FJ, Swerlick RA, George VG, Summers S, Bosse DC, et al. HMEC-1: establishment of an immortalized human microvascular endothelial cell line. J Investig Dermatol. 1992;99(6):683-90. https://doi.org/10.1111/15231747.ep12613748.

45. Sekine H, Mimura J, Oshima M, Okawa H, Kanno J, lgarashi K, et al. Hypersensitivity of anyl hydrocarbon receptor-deficient mice to lipopolysaccharide-induced septic shock. Mol Cell Biol. 2009;29(24):6391-400. https://doi.org/10.1128/MCB.0033709. http://www.ncbi.nlm.nih.gov/pubmed/19822660

46. Szoke K, Beckstrom KJ, Brinchmann JE. Human adipose tissue as a source of cells with angiogenic potential. Cell Transplant. 2012;21(1):235-50. https://doi.org/10. 3727/096368911X580518. http://www.ncbi.n/m.nih.gov/pubmed/21669039

47. Keebaugh AJ, Sioutas C, Pakbin P, Schauer JJ, Mendez LB, Kleinman MT. Is atherosclerotic disease associated with organic components of ambient fine particles? Sci Total Environ. 2015;533:69-75. https:/doi.org/10.1016/j.scitotenv. 2015.06.048.
48. Vauhkonen M, Kuusi T, Kinnunen PK. Serum and tissue distribution of benzol[a]pyrene from intravenously injected chylomicrons in rat in vivo. Cancer Lett. 1980;11(2):113-9.

49. Remsen JF, Shireman RB. Removal of benzo[a]pyrene from cells by various components of medium. Cancer Lett. 1981;14(1):41-6.

50. Plant AL, Benson DM, Smith LC. Cellular uptake and intracellular localization of benzo(a)pyrene by digital fluorescence imaging microscopy. J Cell Biol. 1985;100(4):1295-308.

51. Izzotti A, De Flora S, Petrilli GL, Gallagher J, Rojas M, Alexandrov K, et al. Cancer biomarkers in human atherosclerotic lesions: detection of DNA adducts. Cancer Epidemiol Biomark Prev. 1995;4(2):105-10.

52. Curfs DM, Knaapen AM, Pachen DM, Gijbels MJ, Lutgens E, Smook ML, et al. Polycyclic aromatic hydrocarbons induce an inflammatory atherosclerotic plaque phenotype irrespective of their DNA binding properties. FASEB J. 2005:19(10):1290-2. https://doi.org/10.1096/fj.04-2269fje.

53. Palkova L, Vondracek J, Trilecova L, Ciganek M, Pencikova K, Neca J, et al. The aryl hydrocarbon receptor-mediated and genotoxic effects of fractionated extract of standard reference diesel exhaust particle material in pulmonary, liver and prostate cells. Toxicol in Vitro. 2015:29(3):438-48. https://doi.org/10. 1016/j.tiv.2014.12.002. https://www.ncbi.nlm.nih.gov/pubmed/25500124

54. de Jager J, Dekker JM, Kooy A, Kostense PJ, Nijpels G, Heine RJ, et al. Endothelial dysfunction and low-grade inflammation explain much of the excess cardiovascular mortality in individuals with type 2 diabetes: the Hoorn study. Arterioscler Thromb Vasc Biol. 2006;26(5):1086-93. https:/doi.org/10.1161/01. ATV.0000215951.36219.a4. https://www.ncbi.n/m.nih.gov/pubmed/16514084

55. Van Tassell BW, Toldo S, Mezzaroma E, Abbate A. Targeting interleukin-1 in heart disease. Circulation. 2013;128(17):1910-23. https://doi.org/10.1161/ CIRCULATIONAHA.113.003199. https://www.ncbi.nlm.nih.gov/pubmed/24146121

56. Awan Z, Genest J. Inflammation modulation and cardiovascular disease prevention. Eur J Prev Cardiol. 2015:22(6):719-33.

57. Bishop-Bailey D, Mitchell JA, Warner TD. COX-2 in cardiovascular disease. Arterioscler Thromb Vasc Biol. 2006:26(5):956-8. https://doi.org/10.1161/01. ATV.0000219672.68024.bc. https://www.ncbi.nlm.nih.gov/pubmed/16627818

58. Walton L, Franklin IJ, Bayston T, Brown LC, Greenhalgh RM, Taylor GW, et al. Inhibition of prostaglandin E2 synthesis in abdominal aortic aneurysms: implications for smooth muscle cell viability, inflammatory processes, and the expansion of abdominal aortic aneurysms. Circulation. 1999;100(1):48-54.

59. Ovrevik J, Refsnes M, Lag M, Holme JA, Schwarze PE. Activation of Proinflammatory responses in cells of the airway mucosa by particulate matter: oxidant- and non-oxidant-mediated triggering mechanisms. Biomol Ther. 2015;5(3):1399-440. https://doi.org/10.3390/biom5031399. https:// www.ncbi.nlm.nih.gov/pubmed/26147224

60. Savouret JF, Berdeaux A, Casper RF. The aryl hydrocarbon receptor and its xenobiotic ligands: a fundamental trigger for cardiovascular diseases. Nutr Metab Cardiovasc Dis : NMCD. 2003;13(2):104-13.

61. Sugamura K, Keaney JF Jr. Reactive oxygen species in cardiovascular disease. Free Radic Biol Med. 2011;51(5):978-92. https://doi.org/10.1016/j. freeradbiomed.2011.05.004. https://www.ncbi.nlm.nih.gov/pubmed/21627987

62. Vogel CF, Sciullo E, Matsumura F. Activation of inflammatory mediators and potential role of ah-receptor ligands in foam cell formation. Cardiovasc Toxicol. 2004:4(4):363-73.

63. Korashy HM, El-Kadi AO. The role of aryl hydrocarbon receptor in the pathogenesis of cardiovascular diseases. Drug Metab Rev. 2006;38(3):411-50. https://doi.org/10.1080/03602530600632063. https://www.ncbi.nlm.nih.gov/ pubmed/16877260

64. Tithof PK, Elgayyar M, Cho Y, Guan W, Fisher AB, Peters-Golden M. Polycyclic aromatic hydrocarbons present in cigarette smoke cause endothelial cell apoptosis by a phospholipase A2-dependent mechanism. FASEB J. 2002; 16(11):1463-4. https://doi.org/10.1096/fj.02-0092fje.

65. Xu X, Hu H, Kearney GD, Kan H, Sheps DS. Studying the effects of polycyclic aromatic hydrocarbons on peripheral arterial disease in the United States. Sci Total Environ. 2013;461-462:341-7. https://doi.org/10.1016/j.scitotenv. 2013.04.089. https://www.ncbi.nlm.nih.gov/pubmed/23747551

66. Kang JJ, Cheng YW. Polycyclic aromatic hydrocarbons-induced vasorelaxation through activation of nitric oxide synthase in endothelium of rat aorta. Toxicol Lett. 1997:93(1):39-45.

67. Podechard N, Lecureur V, Le Ferrec E, Guenon I, Sparfel L, Gilot D, et al. Interleukin-8 induction by the environmental contaminant benzo(a)pyrene is aryl hydrocarbon receptor-dependent and leads to lung inflammation. Toxicol Lett. 2008;177(2):130-7. https://doi.org/10.1016/j.toxlet.2008.01.006. https://www.ncbi.nlm.nih.gov/pubmed/18289803 
68. Matsumura F. The significance of the nongenomic pathway in mediating inflammatory signaling of the dioxin-activated ah receptor to cause toxic effects. Biochem Pharmacol. 2009;77(4):608-26. https://doi.org/10.1016/j.bcp. 2008.10.013. https://www.ncbi.nlm.nih.gov/pubmed/18996358

69. Tsai M-J, Hsu Y-L, Wang T-N, Wu L-Y, Lien C-T, Hung C-H, et al. Aryl hydrocarbon receptor (AhR) agonists increase airway epithelial matrix metalloproteinase activity. J Mol Med. 2014; https://doi.org/10.1007/s00109-014-1121-x.

70. Puga A, Ma C, Marlowe JL. The aryl hydrocarbon receptor cross-talks with multiple signal transduction pathways. Biochem Pharmacol. 2009;77(4):71322. https://doi.org/10.1016/j.bcp.2008.08.031. https://www.ncbi.nlm.nih.gov/ pubmed/18817753

71. Cherng TW, Paffett ML, Jackson-Weaver O, Campen MJ, Walker BR, Kanagy NL. Mechanisms of diesel-induced endothelial nitric oxide synthase dysfunction in coronary arterioles. Environ Health Perspect. 2011;119(1):98103. https://doi.org/10.1289/ehp.1002286.

72. Kubatova A, Dronen LC, Picklo MJ Sr, Hawthorne SB. Midpolarity and nonpolar wood smoke particulate matter fractions deplete glutathione in RAW 264.7 macrophages. Chem Res Toxicol. 2006;19(2):255-61. https://doi.org/10.1021/tx050172f.

73. Kubátová A, Lahren TJ, Beránek J, Smoliakova IP, Braun A, Huggins FE. Extractable organic carbon and its differentiation by polarity in diesel exhaust, wood smoke, and urban particulate matter. Aerosol Sci Technol. 2009:43(7):714-29. https://doi.org/10.1080/02786820902889853.

74. Stevens T, Cho SH, Linak WP, Gilmour Ml. Differential potentiation of allergic lung disease in mice exposed to chemically distinct diesel samples. Toxicol Sci. 2009;107(2):522-34. https://doi.org/10.1093/toxsci//kn248. https://www. ncbinlm.nih.gov/pubmed/19074765

75. Cochran RE, Kubátová A. Pressurised fluid extraction of polycyclic aromatic hydrocarbons and their polar oxidation products from atmospheric particles. Int J Environ Anal Chem. 2015;95(5):434-52. https://doi.org/10. 1080/03067319.2015.1025225

76. Boquest AC, Shahdadfar A, Fronsdal K, Sigurjonsson O, Tunheim SH, Collas $P$, et al. Isolation and transcription profiling of purified uncultured human stromal stem cells: alteration of gene expression after in vitro cell culture. Mol Biol Cell. 2005;16(3):1131-41. https://doi.org/10.1091/mbc.E04-10-0949.

77. Bihari P, Vippola M, Schultes S, Praetner M, Khandoga AG, Reichel CA, et al. Optimized dispersion of nanoparticles for biological in vitro and in vivo studies. Part Fibre Toxicol. 2008;5:14. https://doi.org/10.1186/1743-8977-5-14.

Ready to submit your research? Choose BMC and benefit from:

- fast, convenient online submission

- thorough peer review by experienced researchers in your field

- rapid publication on acceptance

- support for research data, including large and complex data types

- gold Open Access which fosters wider collaboration and increased citations - maximum visibility for your research: over $100 \mathrm{M}$ website views per year

At BMC, research is always in progress.

Learn more biomedcentral.com/submissions 